\title{
Biogas residues in substitution for chemical fertilizers: A comparative study on a grassland in the Walloon Region 证放败
}

\author{
Bella Tsachidou ${ }^{\mathrm{a}, \mathrm{e}, *}$, Marie Scheuren ${ }^{\mathrm{b}}$, Jérôme Gennen ${ }^{\mathrm{c}}$, Vincent Debbaut ${ }^{\mathrm{b}}$, Benoît Toussaint ${ }^{\mathrm{d}}$, \\ Christophe Hissler ${ }^{\mathrm{a}}$, Isabelle George ${ }^{\mathrm{e}}$, Philippe Delfosse ${ }^{\mathrm{a}, 1}$ \\ a Luxembourg Institute of Science and Technology, ERIN, Belvaux, Luxembourg \\ b Université de Liège, Département des Sciences de la Vie, Faculté des Sciences, Liège, Belgium \\ c Agra-Ost a.s.b.l., Sankt-Vith, Belgium \\ ${ }^{\mathrm{d}}$ Au Pays de l'Attert, a.s.b.l., Attert, Belgium \\ e Université Libre de Bruxelles, Laboratoire d'Ecologie des Systèmes Aquatiques, Bruxelles, Belgium
}

\section{H I G H L I G H T S}

- Use of biogas residues as biofertilizers mitigates nitrate leaching risk.

- Biomass yield and $\mathrm{N}$ uptake are similar for biogas residues and chemical fertilizers.

- Partial substitution of synthetic $\mathrm{N}$ by biogas residues has environmental benefits.

- Higher organic and synthetic $\mathrm{N}$ rate does not lead to higher agronomic performance.

- Annual rainfall can affect the utilization and losses of plant available nitrogen.

\section{A R T I C L E I N F O}

\section{Article history:}

Received 26 November 2018

Received in revised form 9 February 2019

Accepted 15 February 2019

Available online 17 February 2019

Editor: Jay Gan

\section{Keywords:}

Agricultural pollution

Agronomic performance

Anaerobic digestion

Biofertilizers

Nitrate leaching

Nutrient recycling
G R A P H I C A L A B S T R A C T

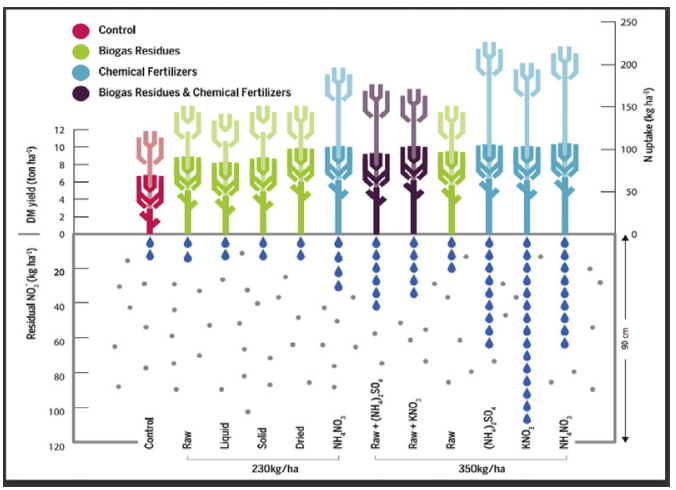

\section{A B S T R A C T}

To provide sufficient quantities of food and feed, farming systems have to overcome limiting factors such as the nutrient depletion of arable soils. Nitrogen being the main mineral element required for plant growth, has led to the extensive use of chemical fertilizers causing nitrogen pollution of the ecosystems. This field study investigates the use of biogas residues (BRs) as biofertilizers and their contribution to the mitigation of nitrate leaching in agricultural soils, while also demonstrating the polluting nature of chemical fertilizers. Nine different fertilization treatments classified in three schemes and two nitrogen doses were tested for three consecutive years on a grassland in the Walloon Region of Belgium. Residual soil mineral nitrogen, percentage contribution of treatments in residual nitrate and agronomic performance were assessed for each fertilization treatment. The results obtained showed significant differences on treatment and scheme level regarding nitrate accumulation in the soil, with chemical fertilizers posing the highest nitrate leaching risk. BRs did not cause nitrate accumulation in the soil, and were $\mathrm{N}$ rate and rainfall independent, while the chemical treatments indicated a cumulative tendency under high $\mathrm{N}$ rate and low precipitation. Forage yield did not demonstrate statistical differences on treatment and scheme level but varied with changing precipitation, while the maximum application rate suggested a

\footnotetext{
it BRs: Biogas Residues.

故弥 FCNA: Fertilizer Contribution to Nitrate Accumulation.

* Corresponding author at: Luxembourg Institute of Science and Technology, ERIN, Belvaux, Luxembourg. E-mail address: bella.tsachidou@list.lu (B. Tsachidou).

${ }^{1}$ University of Luxembourg, Maison du Savoir, 2, avenue de l'Université, L-4365 Esch-sur-Alzette, Luxembourg.
} 
plateau. Aboveground nitrogen content was significantly higher after the application of chemical fertilizers only in the first year, while all the chemical treatments indicated a dilution effect under elevated annual rainfall. Finally, the partial substitution of chemical fertilizers by raw digestate reduced the concentration of $\mathrm{NO}_{3}^{-}$in the soil without having a negative impact on the yield and $\mathrm{N}$ content of the biomass. These results strongly advocate for the environmental benefits of BRs over chemical fertilizers and underline their suitability as biofertilizers and substitutes for chemical fertilizers in similar agricultural systems.

(c) 2019 Published by Elsevier B.V.

\section{Introduction}

As the human population is constantly growing, agriculture aims to increase the yield of crops to provide sufficient quantities of food and feed. To meet this challenge, farming systems have to overcome limiting factors such as the nutrient depletion of arable soils. Nitrogen is an essential mineral element required for plant growth, functioning and formation (Hawkesford and Howarth, 2011; Wienhold et al., 1995). This has led to its industrial transformation (220 $\mathrm{Tg} \mathrm{N} \mathrm{yr}^{-1}$ ) (Fowler et al., 2015) causing a nitrogen cascade through the environmental media (Galloway et al., 2003). The environmental cost of all $\mathrm{N}$ losses in Europe is calculated at 70-320 billion euros per year, which outweighs the economic benefits of $\mathrm{N}$ in agriculture (Sutton et al., 2011). Different aspects of reactive nitrogen $\left(\mathrm{NH}_{3}, \mathrm{NOx}, \mathrm{N}_{2} \mathrm{O}, \mathrm{NO}_{3}^{-}\right)$pollution have led to the establishment of treaties, commissions and legal instruments in Europe putting constraints on the use of fertilizers on agricultural lands. The contamination of drinking water was, inter alia, the main driver for the enactment of the European Nitrates Directive 91/676/ EEC, which aims to protect ground and surface waters from agricultural nitrate leaching, setting the threshold of $50 \mathrm{mg} \mathrm{NO}_{3}^{-} \mathrm{L}^{-1}$ (EEC Council Directive, 1991), mainly in countries such as Belgium, France and Germany, where N input exceeds $300 \mathrm{~kg} \mathrm{~N} \mathrm{ha}^{-1} \mathrm{yr}^{-1}$ (Velthof et al., 2014). However, to date, specific measures within the Nitrates Action Programmes for the Walloon Region in Belgium have established the total quantity of nitrogen (organic and mineral) applicable to $350 \mathrm{~kg} \mathrm{~N} \mathrm{ha} \mathrm{yr}^{-1}$, restricting livestock manure application to $230 \mathrm{~kg} \mathrm{~N} \mathrm{ha}^{-1} \mathrm{yr}^{-1}$ for the grasslands, and to $170 \mathrm{~kg} \mathrm{~N} \mathrm{ha}^{-1}$ for the nitrate vulnerable zones (Grant et al., 2011). These measures are considered impractical by farmers and eventually lead to excessive mineral fertilization and the consequent increase of nitrate loads in the soil and groundwater. To achieve the sustainable management of nitrogen in regions with extensive agricultural activity, either a reduction in inputs, an enhanced recovery in products or an increased storage capacity of nitrogen within the agricultural system is required (Cuttle and Scholefield, 1995).

To prevent further acceleration of environmental pollution caused by chemical fertilizer production and use in agriculture, the recycling of anaerobically digested organic wastes from various sources such as agriculture, food/feed industries, households and more, back to arable lands, seems to be a promising approach. Anaerobic digestion (AD) is an environmentally sound multipurpose process (with the smallest ecological footprint) (Anton and Steinicke, 2012) that generates both cost competitive bioenergy in the form of biogas and biofertilizer as digestate (biogas residues, BRs) (Lukehurst et al., 2010). The biogas residues resulting from the anaerobic digestion are not waste but a valuable co-product, which contains all the nutrients initially present in the substrate (Corré and Conijn, 2016). Therefore, they can be used as a biofertilizer, recycling nutrients such as nitrogen, phosphorus and potassium back to agricultural soils (Abubaker, 2012) while improving soil quality (Nkoa, 2014). Furthermore, developing digestate treatment technologies have the potential to provide concentrated biofertilizers of high-value while allowing the recovery of the water contained in the liquid fraction of biogas residues and the reduction of transportation costs (Adam et al., 2018). Moreover, the on-farm anaerobic digestion of readily available organic resources can cover the demands of the farm in heat and power, while implementation on a global scale has the potential to reduce gross greenhouse gas emissions by $10 \%$ (Tsachidou et al., 2018). The number of biogas plant reactors is drastically increasing (in Europe from 6227 installations in 2009 to 17,662 in 2016, 12,496 of which run on agricultural substrates) (EBA, 2017) as a response to the worldwide energy demands, high fossil fuel prices, climate change, the need for treatment and disposal of organic wastes, among others. This growth produces large amounts of biogas residues (128 million tonnes per year in Europe - EBA, 2017) that require immediate handling (Angelidaki et al., 2003).

Even though the residues from the anaerobic digestion process are a relatively new type of fertilizer, there are a number of research publications that highlight their benefits for soil and plants (Chiew et al., 2015; Koszel and Lorencowicz, 2015; Liu et al., 2009; Odlare et al., 2008). However, owing to the wide range of organic materials used in the process of anaerobic digestion, the residues generated create concerns due to their potential content of heavy metals, organic pollutants, pesticides and pathogens. Nevertheless, biogas residues are known to be particularly rich in ammonium nitrogen (Möller, 2015; Losak et al., 2014) and organic matter, which induce soil biological activity (Alburquerque et al., 2012).

An important physicochemical property that stresses the significance of the nitrogen form in biogas residues is the different ability of $\mathrm{NH}_{4}^{+}$and $\mathrm{NO}_{3}^{-}$ions to be retained on the soil cation exchange complex. Since the surface of most soil particles has fixed negative charges, $\mathrm{NH}_{4}^{+}$ adsorbs strongly to these sites and shows seasonal and spatial homogeneity, therefore providing plants with the required nitrogen in the longterm. On the other hand, $\mathrm{NO}_{3}^{-}$, which is the main source of nitrogen in most chemical fertilizers, as an anion, does not bind to soil particles (Bloom, 2010) and consequently can move freely through the soil (Tinker and Nye, 2000), with the potential of invading the underground water reserves while depriving plants of available nitrogen (Marschner, 2012). Another considerable reason to distinguish the two ions is the difference between the energy required for the plants to acquire $\mathrm{NH}_{4}^{+}$ and $\mathrm{NO}_{3}^{-}$, which may have an impact on their growth (Bloom et al., 1993). In order for the plants to synthesize proteins and other essential nitrogenous compounds, nitrate absorbed from the soil must be first reduced to ammonia before entering the amino acid synthesis process (Jackson et al., 2008; Haynes, 1986). The reactions involved in this transformation are among the most energy intensive processes and have a great expenditure of $12 \mathrm{ATPs}$ per $\mathrm{NO}_{3}^{-}$assimilated, consuming $25 \%$ of the total plant energy in shoots (Bloom et al., 1989) and roots (Bloom et al., 1992). According to Bloom et al. (1992), barley plants consumed less than one-fifth of the energy for root nitrogen acquisition under $\mathrm{NH}_{4}^{+}$nutrition compared to $\mathrm{NO}_{3}^{-}$. By examining the kinetics of ammonium and nitrate uptake in maize root experiments, it was shown that exogenously supplied $\mathrm{NH}_{4}^{+}$was absorbed more than $\mathrm{NO}_{3}^{-}$ when both forms were present in the medium (Taylor and Bloom, 1998). Other studies on $\mathrm{N}$ fluxes in rice and maize seedlings showed that net $\mathrm{NH}_{4}^{+}$uptake was significantly greater than $\mathrm{NO}_{3}^{-}$when both compounds were supplied (Colmer and Bloom, 1998). These findings indicate that biogas residues, being rich in $\mathrm{NH}_{4}^{+}$, have apparent advantages over chemical fertilizers and the potential to contribute towards more sustainable agricultural practices. Nevertheless, factors such as soil $\mathrm{pH}$ and texture, properties of biogas residues, season and methods of application should be considered as they may lead to $\mathrm{N}$ loss through $\mathrm{NH}_{4}^{+}$nitrification and $\mathrm{NH}_{3}$ volatilization, as well as to insufficient $\mathrm{NH}_{4}^{+}$ 
availability due to clay mineral fixation (Scherer et al., 2014), decreasing the utilization percentage and therefore the fertilizer value of BRs.

In contrast to most organic fertilizers, such as manure and composts, which have been extensively investigated, organic residues, such as BRs, are poorly documented. The long-term effect of biogas residues on soil properties remains an unexplored field of research (Nkoa, 2014), while references concerning potential nitrate leaching under fertilization with biogas residues are limited (Svoboda et al., 2013). Therefore, despite their potential, the use of BRs as biofertilizers is limited due to a lack of confidence in their quality and safety (Seadi et al., 2012). The overarching purpose of the current study is to investigate the contribution of different biogas residue fractions to the mitigation of nitrate leaching in the soil and their impact on the agronomic performance of the grasslands in the Walloon Region. Another aim is to establish scientific evidence on the polluting nature of chemical fertilizers, and the environmental benefits resulting from their substitution by biogas residues. Lastly, we seek to prove that providing the total admissible quantity of nitrogen through fertilization with biogas residues would not increase the risk of nitrate leaching as opposed to chemical fertilization.

The work described here is part of a larger research programme on the integration of the biogas sector in the circular bioeconomy, which is carried out through the consecutive INTERREG projects "OPTIBIOGAZ", "ECOBIOGAZ" and "PERSEPHONE".

\section{Materials and methods}

\subsection{Site description}

The current study is part of an ongoing long-term experiment established in early 2013 on a grassland located in the commune of Attert, near Arlon, a Walloon municipality of Belgium (49.745665 N; $5.812498 \mathrm{E}$ ). About $45 \%$ of the Walloon Region corresponds to utilized agricultural land - of which $50 \%$ is pastureland and 50\% arable land (Grant et al., 2011). The trial site has been a permanent meadow for over 20 years and had never been exposed to BRs or chemical fertilizers before the onset of the experiment in 2013. However, before the initiation of this experiment, the land was used for grazing. The vegetation growing on the grassland consists mainly of Lolium perenne, Phleum pratense, Trifolium repens and Trifolium pratense, with their roots reaching 40 to $80 \mathrm{~cm}$ deep. The soil profile of the experimental site is a light sandy loam with moderate to imperfect natural drainage. Prior to the trial, the chemical soil characteristics were evaluated and are summarized in Table 1. The Walloon Region has an Atlantic temperate climate with annual rainfall that amounts to $1014 \mathrm{~mm} \mathrm{yr}^{-1}$ (Grant et al., 2011) and an average temperature of $8.5^{\circ} \mathrm{C}$. The cumulative monthly precipitation and mean monthly temperature, recorded during the field trial, were obtained from the meteorological station of Useldange in Luxembourg, due to its proximity (Fig. 1). This paper demonstrates the results obtained in the first three consecutive years of the experiment, from 2013 to 2015.

Table 1

Soil characteristics of the grassland measured prior to the onset of the experiment in 2013.

\begin{tabular}{llll}
\hline Parameters & $0-30 \mathrm{~cm}$ & $30-60 \mathrm{~cm}$ & $60-90 \mathrm{~cm}$ \\
\hline \% sand & 41.0 & 34.5 & 35.2 \\
\% silt & 9.2 & 9.6 & 5.5 \\
$\%$ clay & 49.8 & 55.9 & 59.3 \\
$\% \mathrm{C}_{\text {org }}$ & 1.83 & 0.60 & 0.62 \\
$\% \mathrm{~N}_{\text {org }}$ & 0.27 & 0.15 & 0.15 \\
$\mathrm{pH} \mathrm{H} \mathrm{H}_{2} \mathrm{O}$ & 6.3 & 6.1 & 5.7 \\
$\mathrm{pH} \mathrm{KCl}$ & 5.2 & 4.6 & 4,1 \\
\hline
\end{tabular}

\subsection{Experimental design}

Nine different fertilization treatments classified into three schemes (biogas residues, chemical fertilizers and their combination) (Table 2) were evaluated and compared to an unfertilized control and to each other. The biogas residues used are a product of the biomethanation plant on site (Ferme du Faascht) and the substrates utilized are mainly liquid and solid bovine manure, crop residues (silage maize and grass) and organic wastes from the food industry. In this study, four different biogas residue fractions were tested separately, while the raw fraction was also tested in combination with chemical fertilizers (Table 2). The chemical characteristics of the BR fractions (Table 3 ) were measured on applied batches using standard analytical methods and the fertilizer amount was adjusted accordingly (based on their nitrogen content) prior to field application. The solid and liquid fractions were obtained with the use of a screw press separator equipped with a $500 \mu \mathrm{m}$ sieve (FAN Separator PSS 3.2-520, GmbH, Germany), while a belt dryer (DORSET, The Netherlands) was used to dry the raw digestate to produce granules of 5-7 mm. The chemical fertilizers tested were ammonium nitrate $\left(13.5 \% \mathrm{NH}_{4}^{+}-\mathrm{N}, 13.5 \% \mathrm{NO}_{3}^{-}-\mathrm{N}\right)$, ammonium sulphate $\left(21 \% \mathrm{NH}_{4}^{+}-\mathrm{N}\right.$, $24 \% \mathrm{~S}$ ) and potassium nitrate $\left(17.4 \% \mathrm{~K}, 13.7 \% \mathrm{NO}_{3}^{-}-\mathrm{N}\right)$. The fertilization treatments were applied in a randomized block design with four replicates per treatment. A total of 56 plots were arranged in 8 parallel rows consisting of 7 plots each. Each plot has dimensions of $10 \mathrm{~m}$ by $2 \mathrm{~m}$, separated by a mowed strip of $1 \mathrm{~m}$ horizontally and $0.5 \mathrm{~m}$ vertically to minimize the edge effect (Fig. 2). Two out of the eleven different treatments initially tested in this field trial were not evaluated in the current paper (treatments $6 \& 10$, as shown in Fig. 2). The fertilizers were weighed and applied by hand aiming the highest possible uniform distribution across the plots. The solid and dried fractions of biogas residues, as well as the chemical fertilizers, were evenly distributed over the plots. The raw and liquid fractions were dispersed with a watering can with a mounted shovel-shaped deflector. The nitrogen rates of the fertilizers tested were $230 \mathrm{~kg} \mathrm{~N} \mathrm{ha}^{-1} \mathrm{yr}^{-1}$ and $350 \mathrm{~kg} \mathrm{~N} \mathrm{ha}^{-1} \mathrm{yr}^{-1}$ in accordance with the maximum admissible doses in the Walloon region (Grant et al., 2011) and the average annual $\mathrm{N}$ inputs in Belgium ( $280 \mathrm{~kg} \mathrm{ha}^{-1}$ in the form of chemical fertilizer and manure from application and grazing) (Jensen et al., 2011). Of the nine different treatments, only raw digestate (RD) and ammonium nitrate (AN) were tested for both $\mathrm{N}$ rates. The total nitrogen dose was divided into instalments allowing the adjustment of fertilizer input to crop demand during the permissible period of application (1st February to 15th September). The main field management practices that took place during the experimental period of 2013 to 2015 and the amount of nitrogen added each time during fertilization are displayed as a timetable in Fig. 3.

\subsection{Residual soil mineral nitrogen}

To assess the nitrogen leaching potential of eleven fertilization treatments and compare them to an unfertilized reference (control) and to each other, soil samples of 0-30, 30-60 and 60-90 cm were collected with a hand auger during the autumn and after the last harvest of each year (Fig. 3). Five cores were collected for each plot and each depth, and were mixed and stored at $4{ }^{\circ} \mathrm{C}$ ( for $<24 \mathrm{~h}$ ) until the analysis. Prior to the analysis for $\mathrm{NO}_{3}-\mathrm{N}$ and $\mathrm{NH}_{4}-\mathrm{N}$, the samples were homogenized through sieving with a mesh of $8 \mathrm{~mm}$. Soil aliquots of $30 \mathrm{~g}$ were mixed with $150 \mathrm{ml}$ of $\mathrm{KCl}$ solution $(0,1 \mathrm{M})$ and placed on a rotating shaker for 30 min before allowing them to stand for an additional 30 min. (Moniteur Belge, 2013). The extract was allowed to settle and the supernatant was used for the quantification of the nitrate and ammonium content in the soil by the colorimetric method of continuous flow analysis (CFA) on a SKALAR SAN + 1050 (ISO11732 for ammonium and ISO 13395 for nitrate). The water content of the soil samples was measured through gravimetry $\left(105^{\circ} \mathrm{C}, 24 \mathrm{~h}\right)$ and was taken into 

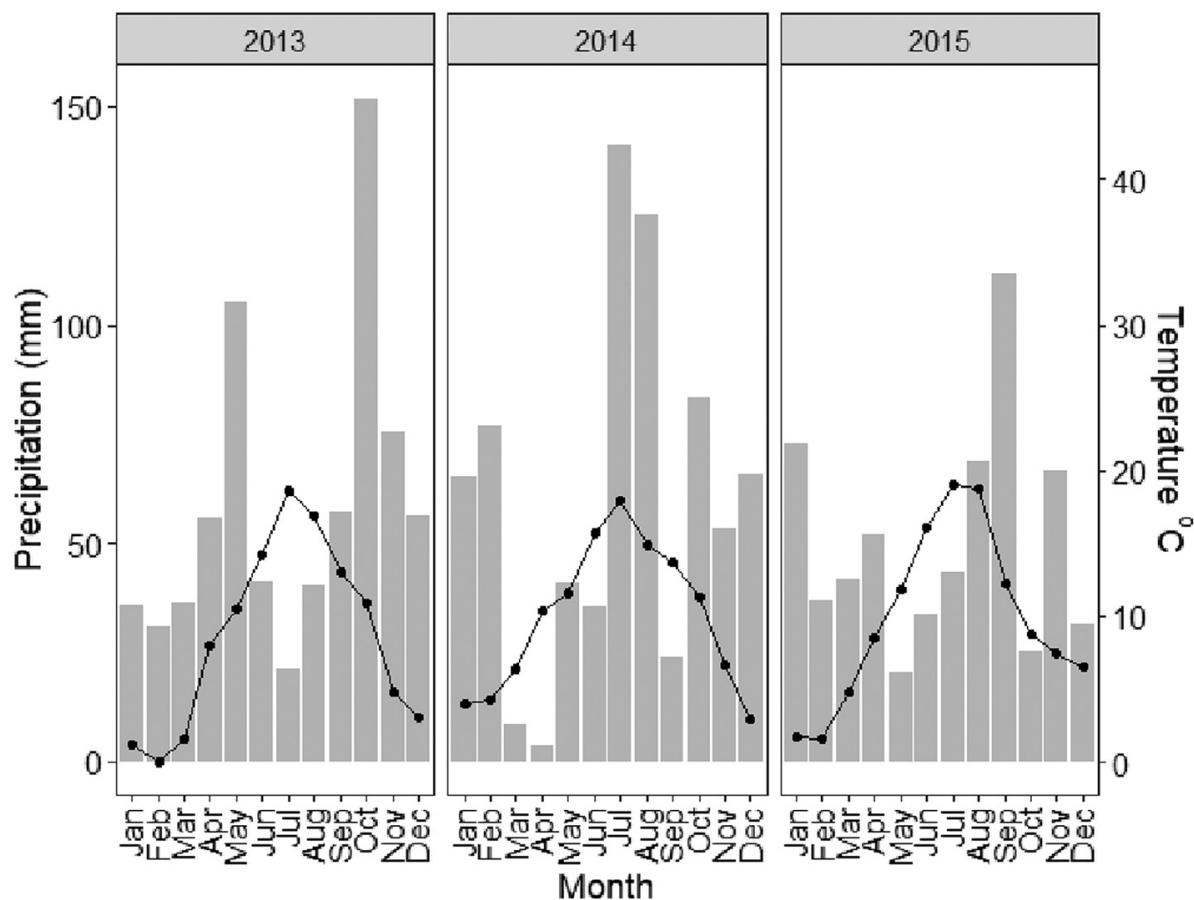

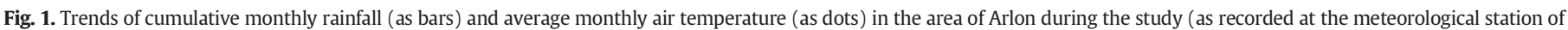
Useldange in Luxembourg).

account to express the $\mathrm{NO}_{3}-\mathrm{N}$ and $\mathrm{NH}_{4}-\mathrm{N}$ values in terms of dry soil weight.

The contribution of each fertilization treatment to the accumulation of nitrate was assessed through the total residual nitrate concentration detected in the soil profile $(0-90 \mathrm{~cm})$ based on the difference method and according to Eq. (1):

Fertilizer Contribution to Nitrate Accumulation (FCNA, \%)

$$
=\left(\mathrm{N}-\mathrm{N}_{0}\right) / \mathrm{F} \times 100
$$

Where: $\mathrm{N}=$ Total nitrate concentration in fertilized plot

$\mathrm{N}_{0}=$ Total nitrate concentration in unfertilized control plot

$\mathrm{F}=$ Quantity of nitrogen applied

\subsection{Nutrient use efficiency}

To obtain the total annual yield, grass was harvested four times per year (Fig. 3) with a Haldrup F-55 grass harvester and the aboveground biomass from each plot was collected and weighed. The harvested

Table 2

Experimental treatments classified into three schemes and two nitrogen doses.

\begin{tabular}{|c|c|c|c|c|}
\hline $\begin{array}{l}\text { Treatment } \\
\mathrm{N}^{\text {oa }}\end{array}$ & Abbreviation & Treatment name & $\begin{array}{l}\text { Total N } \\
\text { Input } \\
\left(\mathrm{kg} \mathrm{ha}^{-1}\right)\end{array}$ & Scheme \\
\hline 1 & CTR & Control & 0 & $\mathrm{~N} / \mathrm{A}$ \\
\hline 2 & RD 230 & Raw Digestate & 230 & Biogas Residue \\
\hline 3 & LD 230 & Liquid Digestate & 230 & Biogas Residue \\
\hline 4 & SD 230 & Solid Digestate & 230 & Biogas Residue \\
\hline 5 & DD 230 & Dried Digestate & 230 & Biogas Residue \\
\hline 7 & AN 230 & $\left(\mathrm{NH}_{4}\right)\left(\mathrm{NO}_{3}\right)$ & 230 & Chemical \\
\hline 8 & RD + AS 350 & $\begin{array}{l}\text { Raw Digestate }+ \\
\left(\mathrm{NH}_{4}\right)_{2} \mathrm{SO}_{4}\end{array}$ & $\begin{array}{l}350(230+ \\
120)\end{array}$ & $\begin{array}{l}\text { Biogas Residue + } \\
\text { Chemical }\end{array}$ \\
\hline 9 & $\begin{array}{l}\mathrm{RD}+\mathrm{PN} \\
350\end{array}$ & $\begin{array}{l}\text { Raw Digestate + } \\
\mathrm{KNO}_{3}\end{array}$ & $\begin{array}{l}350(230+ \\
120)\end{array}$ & $\begin{array}{l}\text { Biogas Residue + } \\
\text { Chemical }\end{array}$ \\
\hline 11 & RD 350 & Raw Digestate & 350 & Biogas Residue \\
\hline 12 & AS 350 & $\left(\mathrm{NH}_{4}\right)_{2} \mathrm{SO}_{4}$ & 350 & Chemical \\
\hline 13 & PN 350 & $\mathrm{KNO}_{3}$ & 350 & Chemical \\
\hline 14 & AN 350 & $\left(\mathrm{NH}_{4}\right)\left(\mathrm{NO}_{3}\right)$ & 350 & Chemical \\
\hline
\end{tabular}

a Corresponds to each tested treatment depicted in Fig. 2. grass was dried at $55^{\circ} \mathrm{C}$ for $48 \mathrm{~h}$ to obtain the dry matter (DM) content for further calculations. The impact of the various fertilization treatments and the two nitrogen rates on the nutrient use efficiency (NUE) measurements was assessed according to Dobermann (2007). As NUE is known to manifest considerable spatial and temporal variability (Fixen et al., 2015), agronomic efficiency and apparent recovery efficiency were calculated as average values.

The dry biomass weight was used to calculate the Agronomic Efficiency $(A E)$ of each fertilization treatment through the difference method and according to Eq. (2):

$\operatorname{AE}\left(\mathrm{kg} \mathrm{DM} \mathrm{kg}^{-1} \mathrm{~N}\right)=\left(\mathrm{Y}-\mathrm{Y}_{0}\right) / \mathrm{F}$

Where: $\mathrm{Y}=$ Yield of aboveground grass biomass of fertilized plot

$\mathrm{Y}_{0}=$ Yield of aboveground grass biomass of unfertilized control plot $\mathrm{F}=$ Quantity of nitrogen applied

Sub-samples of the dry biomass were ground and used for the calculation of the nitrogen uptake per unit of nitrogen applied using the Near Infrared Reflectance Spectroscopy (NIRS) method. The NIRSbased analysis is a standard method used by the accredited soil and forage analytical laboratory of the "Centre de Michamps" in the Walloon region. Two replicates of $5 \mathrm{~g}$ each are used for the analysis and the

Table 3

Mean values of the chemical characteristics of the BR fractions tested over three years.

\begin{tabular}{lllll}
\hline Parameters & RD & LD & SD & DD \\
\hline $\mathrm{N}_{\text {tot }}$ & 5.30 & 5.27 & 7.27 & 21.76 \\
$\mathrm{NH}_{4}^{+}-\mathrm{N}$ & 2.73 & 3.10 & 1.86 & 0.00 \\
$\mathrm{C}: \mathrm{N}$ & 3.80 & 3.79 & 19.63 & 15.83 \\
$\mathrm{DM} \%$ & 6.66 & 6.84 & 36.71 & 90.54 \\
$\mathrm{OM} \%$ & 4.0 & 3.82 & 24.38 & 54.38 \\
$\mathrm{~K}_{2} \mathrm{O}$ & 3.21 & 3.24 & 5.63 & 38.90 \\
$\mathrm{MgO}$ & 0.54 & 0.58 & 6.58 & 8.74 \\
$\mathrm{P}_{2} \mathrm{O}_{5}$ & 2.25 & 2.38 & 8.21 & 32.89 \\
$\mathrm{CaO}$ & 3.88 & 4.14 & 21.63 & 51.63 \\
$\mathrm{pH}$ & 8.19 & 7.85 & 8.51 & - \\
\hline
\end{tabular}

RD: Raw digestate; $L D$ : Liquid phase of screw press ( $500 \mu \mathrm{m})$ separated digestate; $\mathrm{SD}$ : Solid phase of screw press separated digestate; DD: Dried raw digestate on a belt dryer. 


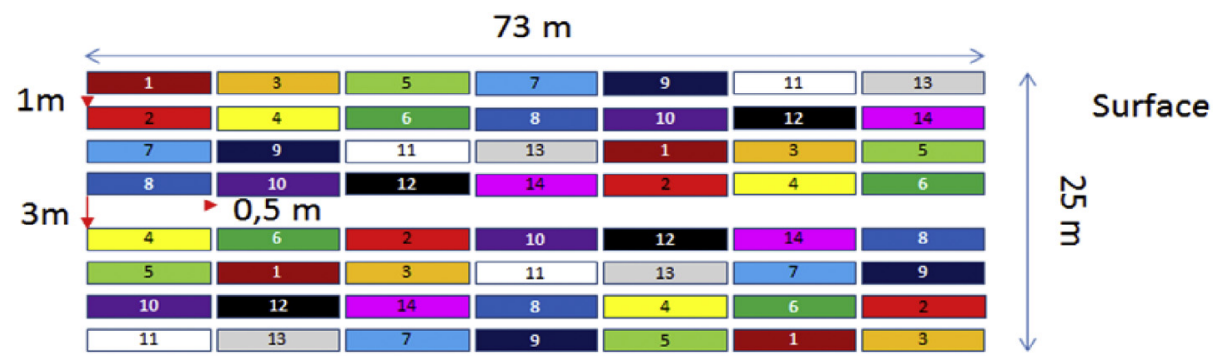

Fig. 2. Experimental site specifics and randomized block design of treatments and their replicates $(n=4)$. Treatments $6 \& 10$ were not evaluated in the current paper.

analytical precision for $\mathrm{N}$ content in plant biomass is $0.5 \%$. The NIRS calibration is maintained and continuously updated with new analytical references obtained from the REQUASUD network and fed in a centralized database which contained over 1 million of validated sample data (http://www.requaconsult.requasud.be/). Based on the data obtained, the Apparent Recovery Efficiency (ARE) was calculated by the difference method and according to Eq. (3):

$\operatorname{ARE}(\%)=\left(\mathrm{U}-\mathrm{U}_{0}\right) / \mathrm{F} \times 100$

Where: $U=$ Nitrogen uptake in aboveground grass biomass of fertilized plot

$\mathrm{U}_{0}=$ Nitrogen uptake in aboveground grass biomass of unfertilized control plot

$\mathrm{F}=$ Quantity of nitrogen applied

\subsection{Statistical analysis}

All data exploration and statistical analyses were performed with $\mathrm{R}$ software (Version 3.4.1). All statistics were considered significant at the threshold $\alpha=0.05(n=4)$. The data describing the yield and aboveground biomass nitrogen content complied with the assumptions of Gaussian distribution and hence, a repeated measures two-way analysis of variance (ANOVA) was performed with the use of the psycho package (Makowski, 2018) to determine the effects of the treatment, year and their interaction, on the dry mass yield and nitrogen content of the forage. When the results indicated statistical differences, a post hoc pair-wise comparison was conducted using Tukey's HSD adjustment.

On the other hand, data describing the residual soil mineral nitrogen did not fulfil the normality condition of the Shapiro Wilk test. Therefore, the rank transformation of data preceded a repeated measures two-way analysis of variance to determine whether fertilization treatment, year and their interaction had a significant effect on the residual nitrate and ammonium concentrations in the soil profile. When statistical significance was indicated, a post-hoc analysis on ranks using Tukey's HSD adjustment was performed with the use of the lsmeans package (Lenth, 2016) to detect significantly different means.

\section{Results}

\subsection{Residual soil nitrate and ammonium distribution in the soil profile}

The major mineral nitrogen form detected in the soil profile, after the last harvest each autumn, was nitrate $\left(\mathrm{NO}_{3}^{-}-\mathrm{N}\right)$. Overall, residual nitrate concentration was higher in the top soil layer of $0-30 \mathrm{~cm}$ for all the treatments and all years compared to the two deeper layers of 30-60 and $60-90 \mathrm{~cm}$ (Fig. 4). Following the application of the biogas residue fractions, the residual nitrate concentration in the top soil layer did not exceed $16 \mathrm{~kg} \mathrm{ha}^{-1}$, even at the maximum fertilization rate of $350 \mathrm{~kg} \mathrm{~N} \mathrm{ha}^{-1}$, over the three years. Most importantly, the concentration of nitrate in the two deeper soil layers did not exceed $5 \mathrm{~kg} \mathrm{ha}^{-1}$. Treatments within the chemical and combinatorial schemes led to a greater accumulation of nitrate in the soil profile, demonstrating significant differences with BRs $(P<0.001)$. In 2015, following the application of PN 350, nitrate concentration reached $87 \mathrm{~kg} \mathrm{ha}^{-1}$ at 30-60 cm and $50 \mathrm{~kg} \mathrm{ha}^{-1}$ at $60-90 \mathrm{~cm}$. The nitrate concentration was lower following the application of combinatorial treatments, compared to chemical fertilizers as the sole $\mathrm{N}$ source, with RD + PN 350 reducing nitrate to $22 \mathrm{~kg} \mathrm{ha}^{-1}$ at $30-60 \mathrm{~cm}$ depth in 2015. A strong year effect $(P<$ 0.001 ) was observed for the chemical treatments (except for AN 230) across all depths as nitrate concentration during 2015 in some cases was tenfold compared to 2013 and 2014. Furthermore, the impact of the $\mathrm{N}$ rate supplied as $\left(\mathrm{NH}_{4}\right)\left(\mathrm{NO}_{3}\right)$ was apparent in 2015 as the

\section{FERTILIZATION HARVEST SAMPLING $230 \mathrm{~kg} \mathrm{~N} / \mathrm{ha} \quad 350 \mathrm{~kg} \mathrm{~N} / \mathrm{ha}$}
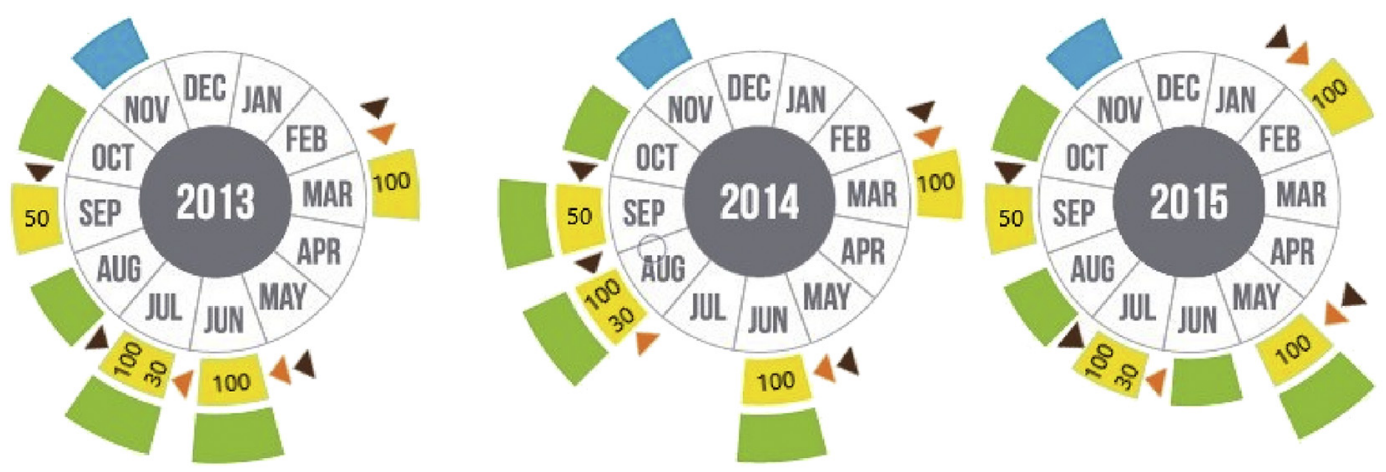

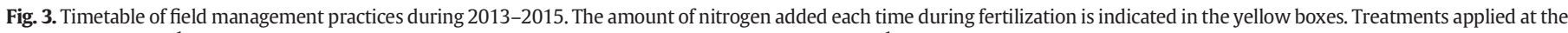

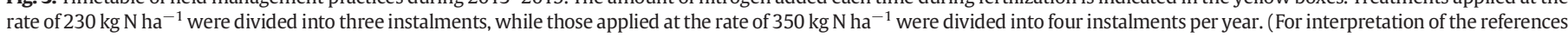
to colour in this figure legend, the reader is referred to the web version of this article.) 

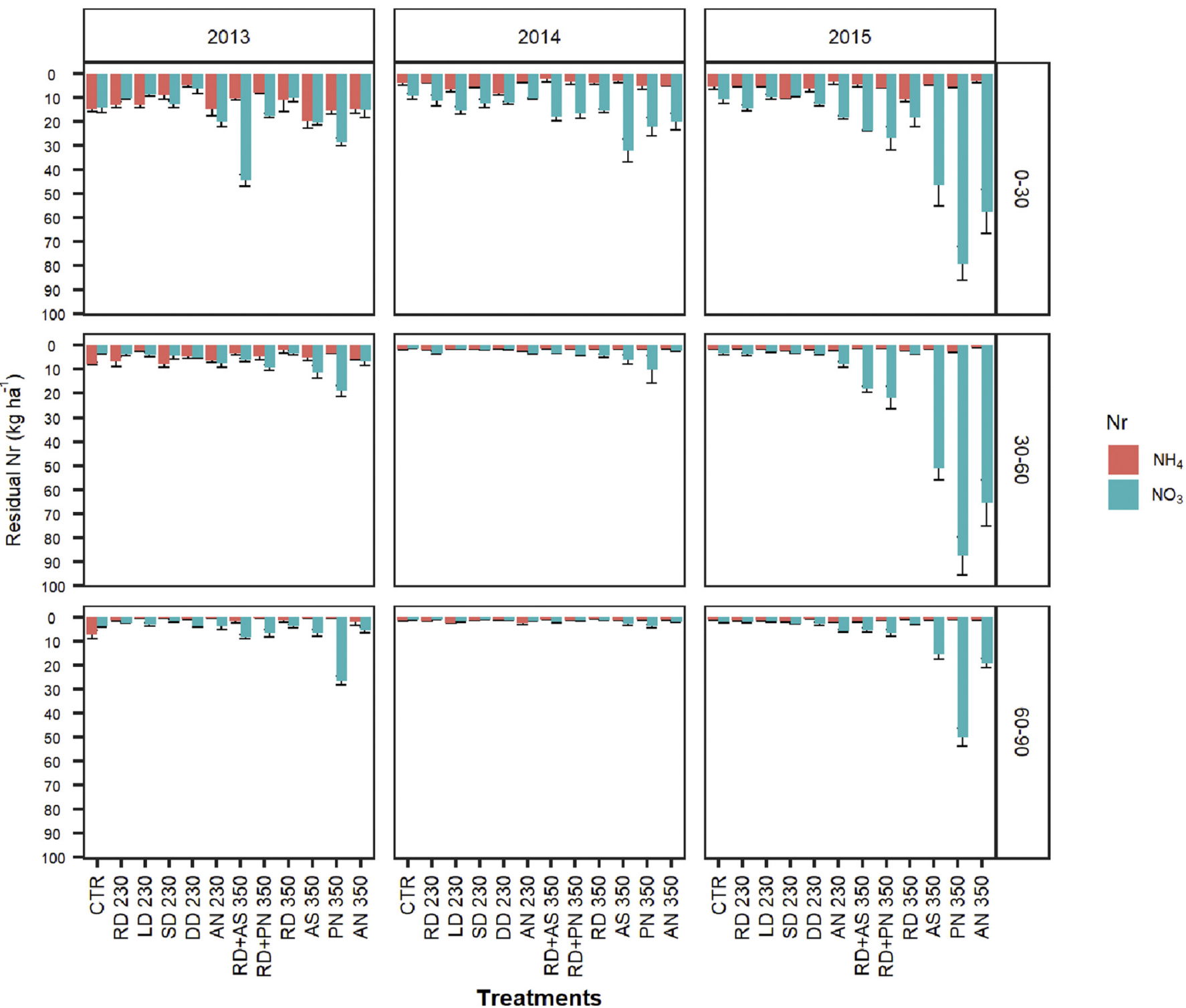

Treatments

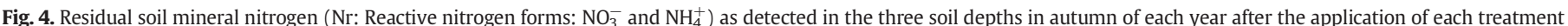

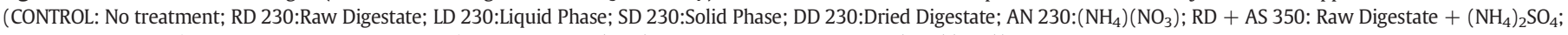
$\mathrm{RD}+\mathrm{PN}$ 350:Raw Digestate + $\mathrm{KNO}_{3} ; \mathrm{RD} 350:$ Raw Digestate; AS 350: $\left.\left(\mathrm{NH}_{4}\right)_{2} \mathrm{SO}_{4} ; \mathrm{PN} 350: \mathrm{KNO}_{3} ; \mathrm{AN} 350:\left(\mathrm{NH}_{4}\right)\left(\mathrm{NO}_{3}\right)\right)$.

accumulation and progressive downward movement of nitrate was significantly higher $(P<0.01)$ under the application of $350 \mathrm{~kg}$ of $\mathrm{N} \mathrm{ha}^{-1}$ (AN 350 ) compared to $230 \mathrm{~kg}$ of $\mathrm{N} \mathrm{ha}^{-1}$ (AN 230). In contrast, the two $\mathrm{N}$ rates tested through raw digestate (RD 230 \& RD 350) application did not have any effect on the nitrate concentration in any of the soil layers and years.

Ammonium detected in the soil profile remained below $10 \mathrm{~kg} \mathrm{ha}^{-1}$ for all treatments and depths, with the exception of the top soil layer in 2013 when most treatments fluctuated between 10 and $20 \mathrm{~kg} \mathrm{ha}^{-1}$. No significant differences were noted between the control plot and the treatments, or among treatments within the same year. In addition, neither year, nor treatment by year interaction was noted. Overall, ammonium concentration was highest in the top soil layer for all treatments over the three years (on average $80 \%$ of the total $\mathrm{NH}_{4}$ was detected in 0-30 cm) and showed no progressive movement in depth (Fig. 4).

\subsection{Treatment contribution to residual soil nitrate}

The contribution of the treatments within the biogas residue scheme to the accumulation of residual nitrate in the soil $(0-90 \mathrm{~cm})$ was at the same level as the unfertilized control, while in the first year of the experiment, their percentage contribution was lower than that observed for the control (Fig. 5). All treatments within both chemical and combinatorial schemes had a significantly $(P<0.01)$ higher contribution to the accumulation of nitrate in the soil compared to the biogas residue fractions, with the highest contribution observed in 2015 for the chemical fertilizers. About $60 \%$ of the nitrate detected in the soil in 2015 following the application of PN 350 was attributed to the treatment. Partial substitution (65\%) of PN 350 by raw digestate in the same year reduced this contribution to $17 \%$. In addition, the rate of total $\mathrm{N}$ applied did not affect the percentage contribution of the raw digestate (RD 230 and RD 350) in any of the three years of the trial, whereas in 2015, AN 350 showed a contribution to the accumulation of residual soil nitrate that was five times higher than AN 230.

\subsection{Impact of treatment on forage yield and agronomic efficiency}

Overall, the yields of the harvested grass were not affected significantly by the treatment within the same year. The yields produced under the application of biogas residue fractions were slightly 


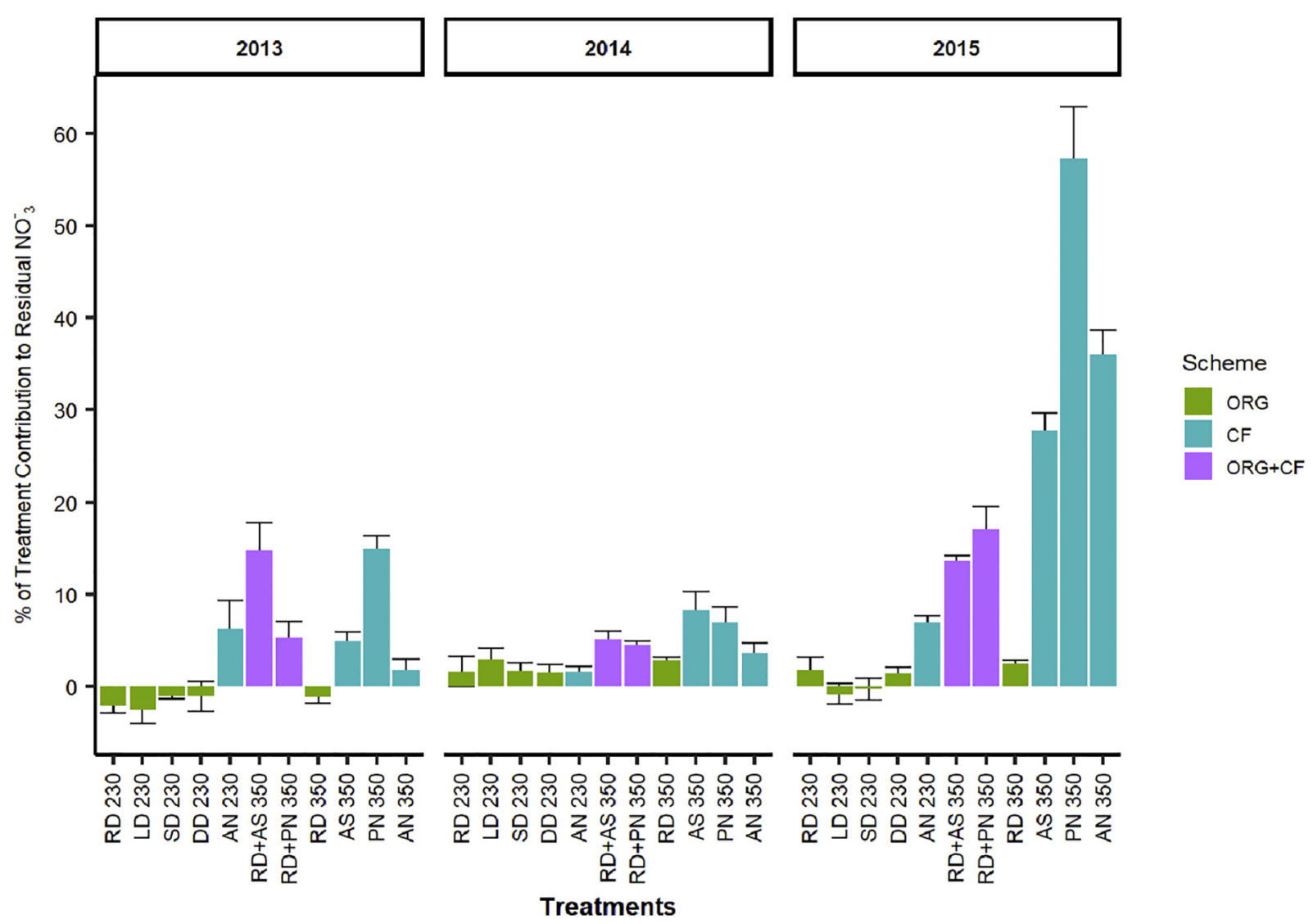

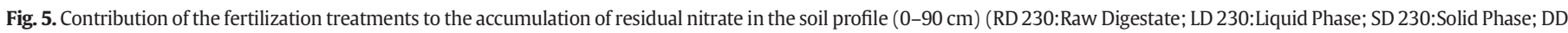

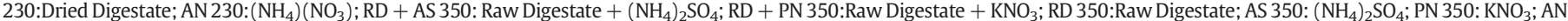
350: $\left(\mathrm{NH}_{4}\right)\left(\mathrm{NO}_{3}\right)$ ). The treatments are grouped in three schemes (BR: Biogas Residues; CF: Chemical Fertilizers; BR + CF: Biogas Residues + Chemical Fertilizers).

lower (in 2013 and 2015) but not statistically different to those obtained under the application of chemical fertilizers and combinatorial treatments (Fig. 6). Statistically significant differences were observed only between the control and chemical and combinatorial treatments in 2013 and 2015. Substituting chemical fertilizers with biogas residues up to $65 \%$ showed no significant reduction in the aboveground biomass produced when compared to the chemical fertilizers as the sole nitrogen source. However, between years, the grass yields showed significant differences $(P<0.001)$, with 2014 yielding the highest biomass, giving on average 12 tons of DM ha ${ }^{-1}$ under the application of BRs and CFs, with RD 230 performing better than all the chemical treatments, and the control producing approximately 9.5 tons of DM ha ${ }^{-1}$. In 2015, the yield obtained was the lowest for the three-year period, with the performance of CFs and BR fractions showing no statistical differences. In addition, the rate of nitrogen (230 and $350 \mathrm{~kg} \mathrm{ha}^{-1}$ ) did not have any impact on the grass yield within the same year, neither for raw digestate (RD 230 and RD 350) nor for ammonium nitrate (AN 230 and an 350), thus indicating a plateau effect.

The average Agronomic Efficiency calculated for all three years did not exceed $14 \mathrm{~kg}$ of DM kg-1 of $\mathrm{N}$ applied for most of the treatments tested. However, the scheme of chemical fertilizers demonstrated the highest efficiency in 2013 and 2015 (Fig. 6). The rate of nitrogen applied as raw digestate did not affect the AE, except in 2014 when the efficiency of RD 230 was double the efficiency of RD 350. On the other hand, for ammonium nitrate (AN 230 and AN 350 ), the impact of the $\mathrm{N}$ rate on the crop yield increase per $\mathrm{kg}$ of nitrogen applied, revealed higher efficiency when the $\mathrm{N}$ rate was $230 \mathrm{~kg} \mathrm{ha}^{-1}$, reaching almost $20 \mathrm{~kg} \mathrm{~kg}^{-1}$ in 2013 and $16 \mathrm{~kg} \mathrm{~kg}^{-1}$ in 2015.

\subsection{Impact of treatment on plant nitrogen uptake and apparent recovery} efficiency

Nitrogen uptake by the aboveground biomass was strongly affected by the fertilization treatment $(P<0.001)$, the trial year $(P<0.001)$ and their interaction $(P<0.05)$. More specifically, in 2013, all the treatments within the chemical fertilization scheme had a great positive impact on the nitrogen uptake, with AS 350 reaching $272 \mathrm{~kg}$ of $\mathrm{N} \mathrm{ha}^{-1}$. Nitrogen uptake under the application of the chemical and combinatorial treatments was not statistically different. The biogas residue factions demonstrated the lowest performance with nitrogen uptake ranging from $140 \mathrm{~kg} \mathrm{ha}^{-1}$ up to $173 \mathrm{~kg} \mathrm{ha}^{-1}$ but did not differ significantly from the combinatorial treatments. However, BRs (except SD 230 and DD 230) and chemical fertilizers showed strong differences regarding nitrogen uptake under the same nitrogen rate in 2013. The following year, there were no statistical differences either between the control and the treatments or among treatments. In 2015, nitrogen uptake was the lowest for all the treatments compared to the two previous years. BRs had no significant differences either with the combinatorial treatments or with the chemical treatments under the same nitrogen rate. The tested rates of $230 \mathrm{~kg} \mathrm{ha}^{-1}$ and $350 \mathrm{~kg} \mathrm{ha}^{-1}$ had no significant effect for either raw digestate or ammonium nitrate (Fig. 7).

The average Apparent Recovery Efficiency was highest in 2013 and lowest in 2014 for all treatments. Overall, the highest aboveground nitrogen uptake per unit of nitrogen applied was observed for the treatments within the chemical scheme, with AN 230 being the most efficient treatment. More specifically, in 2013, almost 50\% of the nitrogen detected in the aboveground plant biomass was attributed to AN 230 (increased $\mathrm{N}$ uptake by $109 \mathrm{~kg} \mathrm{ha}^{-1}$ ), while RD + PN 350 increased nitrogen content by $57 \mathrm{~kg} \mathrm{ha}^{-1}$ and SD 230 by $43 \mathrm{~kg} \mathrm{ha}^{-1}$. In 2014, only 

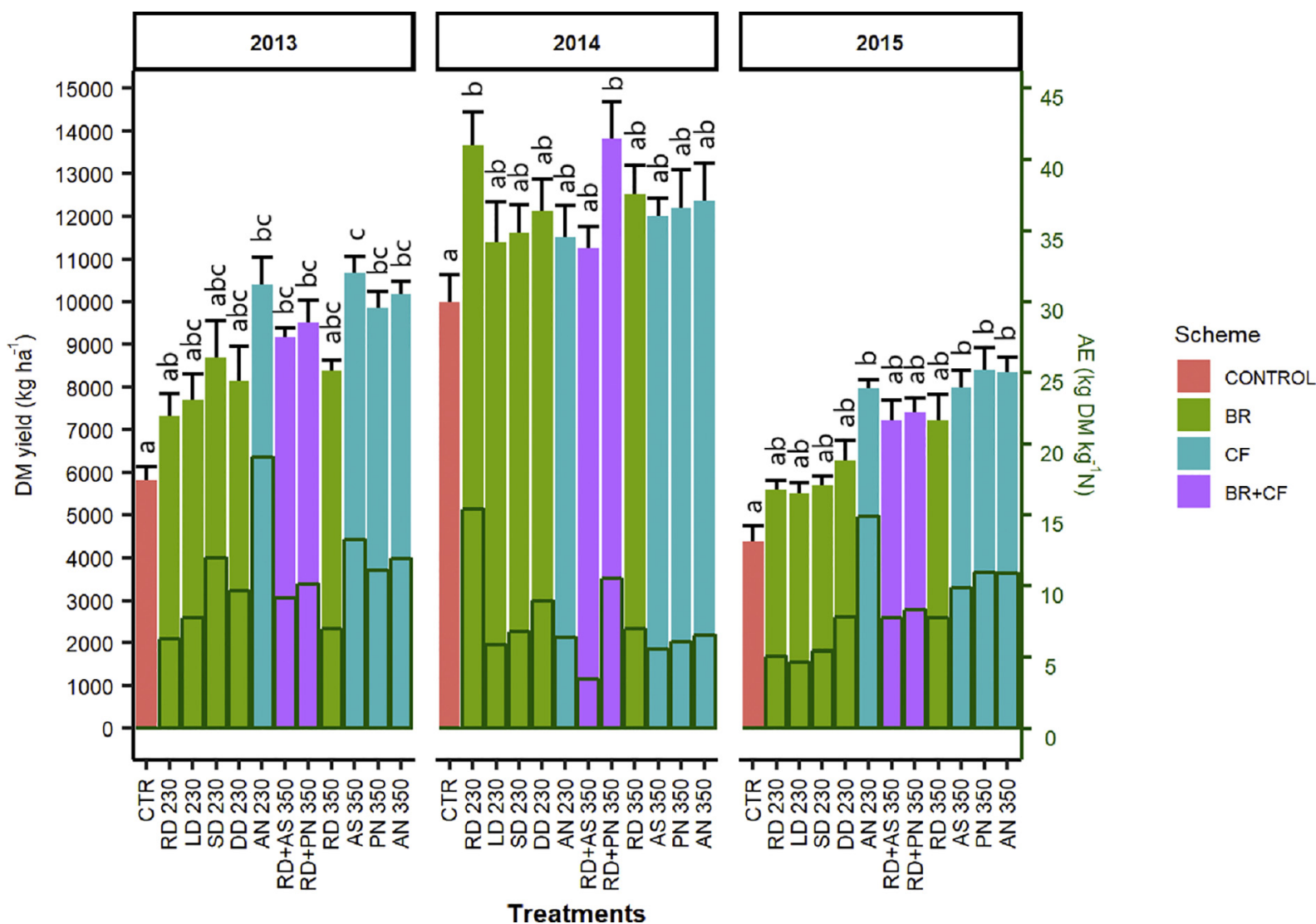

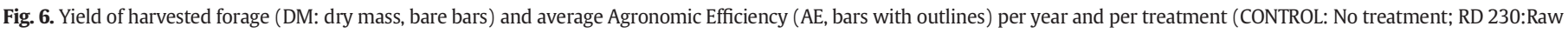

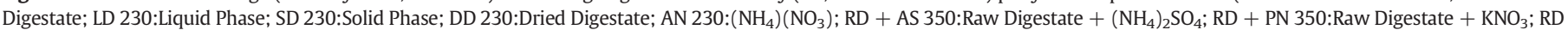
350:Raw Digestate; AS 350: $\left(\mathrm{NH}_{4}\right)_{2} \mathrm{SO}_{4}$; PN 350: $\mathrm{KNO}_{3}$; $\mathrm{AN}$ 350: $\left.\left(\mathrm{NH}_{4}\right)\left(\mathrm{NO}_{3}\right)\right)$. Yield data with the same letter in a column are not significantly different.

$32 \mathrm{~kg}$ of $198 \mathrm{~kg}, 7 \mathrm{~kg}$ of $177 \mathrm{~kg}$ and $9 \mathrm{~kg}$ of $173 \mathrm{~kg} \mathrm{ha}^{-1}$ of $\mathrm{N}$ uptake by the grass was attributed to fertilization with AN 230, RD + PN 350 and SD 230 , respectively. In the last year, the chemical treatments increased $\mathrm{N}$ uptake the most ( $54 \mathrm{~kg} \mathrm{ha}^{-1}$ for AN 230) compared to combinatorial treatments (22 kg ha ${ }^{-1}$ for RD + AS 350) and BR fractions (22 kg ha ${ }^{-1}$ for DD 230). Overall, the ARE was higher for $\left(\mathrm{NH}_{4}\right)\left(\mathrm{NO}_{3}\right)$ when applied at the rate of $230 \mathrm{~kg} \mathrm{ha}^{-1}$, while for the raw digestate the ARE was slightly higher at the rate of $350 \mathrm{~kg} \mathrm{ha}^{-1}$ with the exception of 2014 (Fig. 7).

\subsection{Effect of precipitation on nitrate accumulation and agronomic performance}

To understand how nitrogen utilization and losses may be affected by a changing climate variable such as precipitation, while keeping in mind the strong year effect observed in the previous analyses, we explored the influence of the annual rainfall on residual soil nitrate, DM yield and $\mathrm{N}$ uptake of the aboveground plants. The cumulative amount of residual nitrate detected within $90 \mathrm{~cm}$ of soil under the application of BR fractions was not affected by the annual precipitation and demonstrated the same response as the unfertilized control plot. In contrast, nitrate concentration measured in the plots treated with chemical fertilizers revealed the implication of the annual rainfall in the accumulation of nitrate. More specifically, the trend observed indicates that low annual precipitation (as recorded in 2015) can be conducive to nitrate accumulation when fertilization is performed with high rates of chemical fertilizers. However, nitrate accumulation in the soil under low precipitation was moderated when $65 \%$ of chemical fertilizers were substituted by raw digestate (Fig. 8).

Regarding the dry mass yield - for all the treatments tested, but also for the unfertilized control - the highest yield was noted in 2014 when rainfall was highest (722 mm), while the lowest yield was harvested in 2015 when precipitation was almost half $(604 \mathrm{~mm})$ the regional average (1014 $\mathrm{mm} \mathrm{yr}^{-1}$ ). This observation implied a trend for an increasing yield as annual precipitation increased. The concentration of nitrogen detected in the aboveground plant parts was the lowest for all the treatments and the control when the recorded annual precipitation was only $604 \mathrm{~mm}$ in 2015. For the biogas residue fractions and the control, the increase of rainfall (707 and $722 \mathrm{~mm}$ in 2013 and 2014, respectively) led to an increase of plant nitrogen content. However, for the chemical and combinatorial treatments, nitrogen uptake reached a peak when annual rainfall was $707 \mathrm{~mm}$ but further elevation of precipitation to $722 \mathrm{~mm}$ led to the reduction of nitrogen uptake (Fig. 8).

\section{Discussion}

\subsection{Potential nitrate leaching}

Nitrogen loss through nitrate leaching from the root zone of agricultural lands has a negative impact on the groundwater quality (Marchi et al., 2016) and can reduce soil fertility, thus affecting crop yields (Jabloun et al., 2015). In general, grasslands have a large nitrogen uptake capacity and therefore show a low nitrate leaching risk (Cameron et al., 2013). The nature and rate of the fertilizers used in this grassland experiment and environmental factors such as precipitation, as well as their interaction, seem to determine the soil profile content in mineral nitrogen, mainly in the form of nitrate. More precisely, nitrate concentration was scheme-specific and found to be higher under the application of chemical and combinatorial schemes compared to biogas residues. However, in the interpretation of our results, we should keep in mind the high spatial and temporal variability that characterizes soil systems, and the possible contribution of the manual application of fertilizers to 

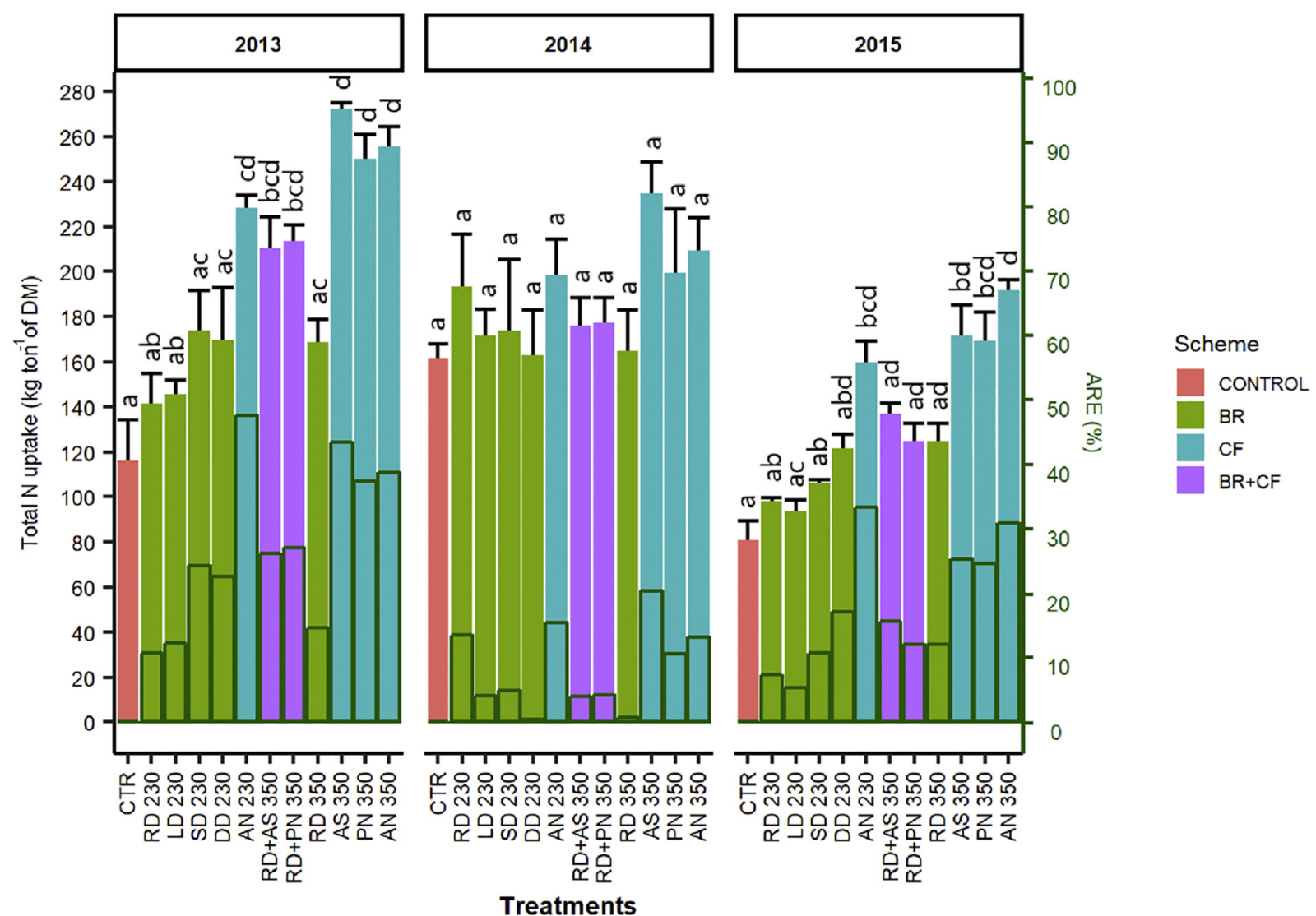

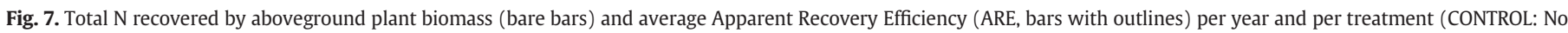

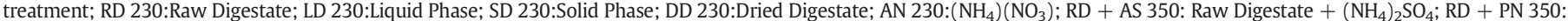

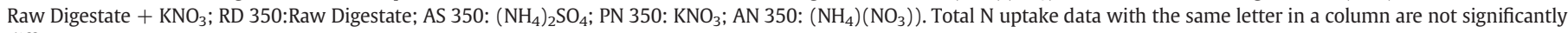
different.

the spatial heterogeneity of the soil. We believe that precise treatment application, frequent sampling and a higher number of replicates in such field trials could provide more reliable data and further reinforce the findings.

The accumulation of nitrate in the soil depends greatly on environmental factors such as water availability, which dictates transformations and losses of nitrogen in the soil (Wang et al., 2006), while allowing $\mathrm{N}$ uptake by the vegetation (Yao et al., 2018). The results of the current study revealed the accumulation of nitrate in all three soil depths, when precipitation amounted to almost half $(604 \mathrm{~mm}$ in 2015) of the annual rainfall for the region (1014 $\left.\mathrm{mm} \mathrm{yr}^{-1}\right)$, under the application of chemical and combinatorial fertilizers (Fig. 8). Similarly, other studies investigating the impact of precipitation on nitrate leaching concluded that there was a negative correlation between high precipitation and nitrate concentration in the extracted soil solution (Huang et al., 2018; Jabloun et al., 2015), which may be attributed to the dilution effect (Beaudoin et al., 2005), and the enhanced denitrification promoted under the anaerobic conditions established in saturated soils (Philippot et al., 2007). However, nitrate accumulation in the soil profile and its loss through leaching and denitrification, could vary in soils of differing texture, under disparate rainfall distribution during seasons or extreme rainfall events and temperatures.

Furthermore, the quantity of the fertilizers applied has a great potential to increase nitrate leaching (Yao et al., 2018; Delin and Stenberg, 2014) especially if it exceeds the uptake capacity of the plants (Guillard et al., 1995). However, in this study, this was the case only for chemical fertilizers but not for BRs as the sole nitrogen source. Increasing the nitrogen rate from $230 \mathrm{~kg} \mathrm{ha}^{-1}$ to $350 \mathrm{~kg} \mathrm{ha}^{-1}$ per year for ammonium nitrate, in 2015, led to the vertical distribution of nitrate and tripled its accumulation in the top soil layer $(0-30 \mathrm{~cm})$, increased it by tenfold at 30-60 cm, and quadrupled it at 60-90 cm (Fig. 4). Therefore, potential nitrate leaching is significantly elevated with the excess application of chemical fertilizers (Lenka et al., 2013), particularly in combination with decreasing water availability (Huang et al., 2018). In contrast, increasing the rate of applied nitrogen in the form of raw digestate from $230 \mathrm{~kg} \mathrm{ha}^{-1}$ to $350 \mathrm{~kg} \mathrm{ha}^{-1}$ per year showed no accumulation or progressive movement of nitrate in the soil profile when annual precipitation was low (2015). Walsh et al. (2012) also demonstrated that the application of mineral fertilizer on grassland led to greater $\mathrm{NO}_{3}^{-}$leaching than cow slurry-based liquid digestate, when levels of soil nutrients exceeded plant requirements. These findings are also in agreement with the results obtained by Svoboda et al. (2013), who showed that the application of chemical fertilizer as calcium ammonium nitrate (CAN), at high nitrogen rates $\left(360 \mathrm{~kg} \mathrm{ha}^{-1}\right.$ ), resulted in nitrate concentrations above the EU drinking water threshold, while corresponding BRs, obtained through co-fermented pig slurry/maize, remained below that threshold and at significantly lower levels compared to CAN. These results strongly confirm our hypothesis that - in the short-term - BRs applied as the sole nitrogen source and at the maximum rate of $350 \mathrm{~kg} \mathrm{~N} \mathrm{ha}^{-1} \mathrm{yr}^{-1}$ do not increase the potential nitrate leaching risk in contrast to chemical fertilizers. However, to be able to make estimates about the long-term consequences, it is necessary to consider the repeated application of BRs and increased mineralization of accumulating organic N. The lack of data from long-term grassland experiments does not allow the full evaluation of the nitrate leaching potential of BRs in the long-term. Nevertheless, this risk could possibly be mitigated or eliminated with the proper adjustment of the supplementary chemical fertilizers. Substituting chemical fertilizers such as $\mathrm{KNO}_{3}$ and $\left(\mathrm{NH}_{4}\right)_{2} \mathrm{SO}_{4}$ by $65 \%$ with raw digestate has the potential to reduce the accumulation of nitrate in the 


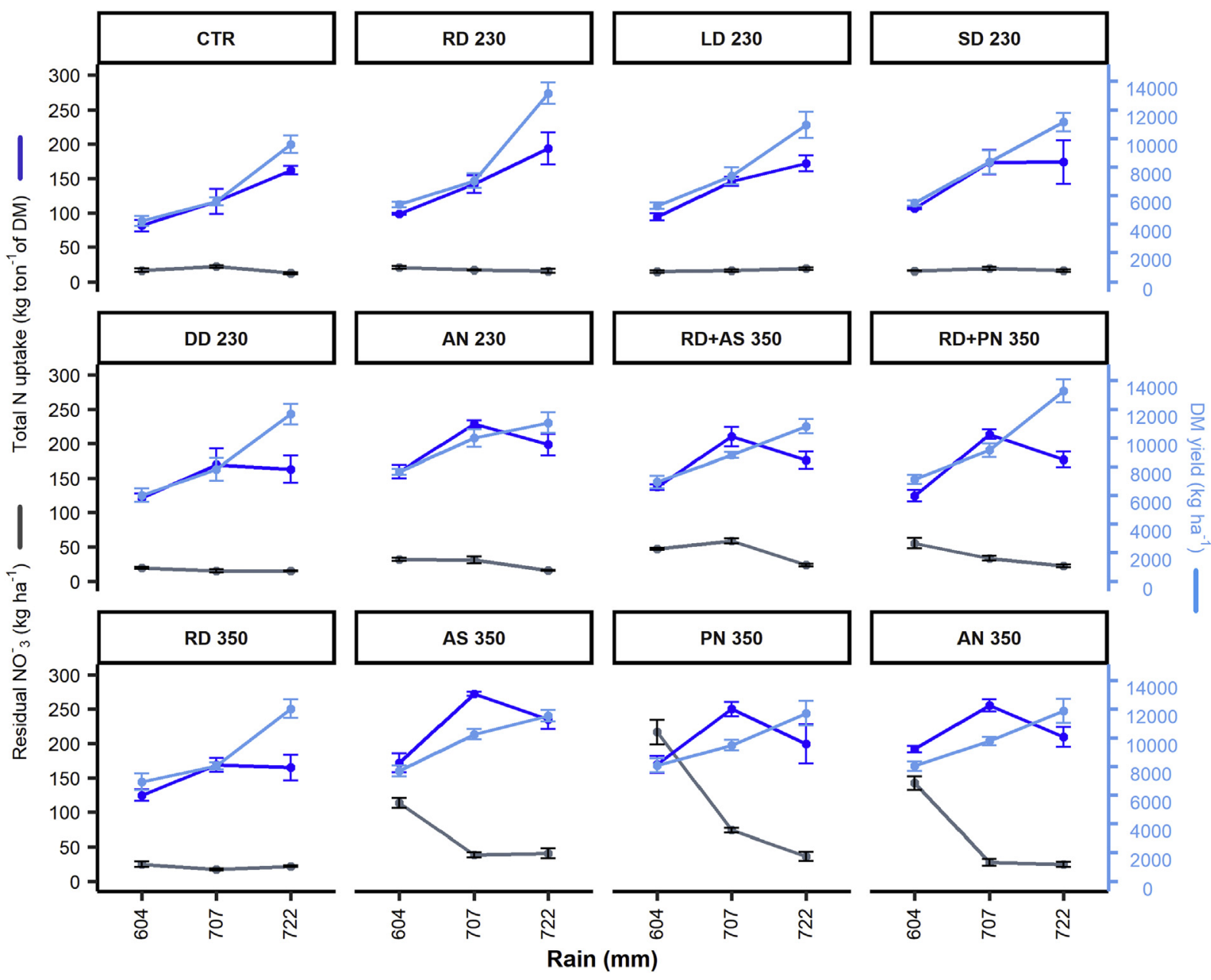

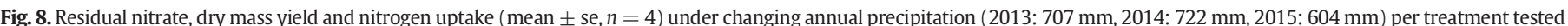

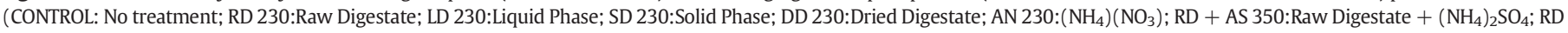
+ PN 350:Raw Digestate + $\mathrm{KNO}_{3} ; \mathrm{RD}$ 350:Raw Digestate; AS 350: $\left.\left(\mathrm{NH}_{4}\right)_{2} \mathrm{SO}_{4} ; \mathrm{PN} 350: \mathrm{KNO}_{3} ; \mathrm{AN} 350:\left(\mathrm{NH}_{4}\right)\left(\mathrm{NO}_{3}\right)\right)$.

soil by $60 \%$ during dry periods. This finding indicates that most of the nitrate load in the soil is explained by the proportion of chemical fertilizers in the combinatorial treatments tested. Furthermore, this could be partially attributed to the high content of BRs in ammonium, which inhibits the nitrification rate by restricting the activity of Nitrobacter in the soil (Monaghan and Barraclough, 1992). To reach a conclusion on the potential of partially replacing chemical fertilizers by BRs, longterm field experiments under various climatic conditions and different substitution rates are required. Moreover, our results do not confirm the hypothesis put forward by other researchers (Kirchmann et al., 2007) claiming a high nitrate loss risk due to the asynchrony of crop demand and nitrogen release from the organic matter when fertilizing with organic fertilizers such as digestate or manure.

Lastly, of particular interest is the elevated concentration of residual nitrate in the soil, recorded under the application of ammonium sulphate (AS 350). Despite the fact that ammonium sulphate $\left(21 \% \mathrm{NH}_{4}^{+}\right.$ and $24 \% \mathrm{SO}_{4}^{2-}$ ) does not introduce any nitrate in the soil upon application, it is among the treatments that demonstrated the highest nitrate accumulation in the soil profile, particularly in the last year of the trial. As ammonium is the main form of nitrogen contained in ammonium sulphate, a behaviour similar to ammonium-rich BRs would be anticipated in the soil. This observation could possibly be explained by the sulphate-reducing ammonium oxidation (SRAO) process, first assumed by Fdz-Polanco et al., 2001. The SRAO process has not been considered under in situ conditions and could provide an insight to biological reactions taking place in agroecosystems between $\mathrm{NH}_{4}^{+}$and $\mathrm{SO}_{4}^{2-}$.

\subsection{Agronomic performance}

Regarding the agronomic performance of the fertilization schemes tested in this experiment, it was demonstrated that BR fractions have the potential to maintain yields in the grasslands of the Walloon Region and potentially provide nitrogen in the long-term due to the slow mineralization of organic N. Overall, for all three years of this field trial, the aboveground biomass yield obtained under the application of the various fractions of BRs was in close proximity with the yield produced under the use of combinatorial treatments, as well as the chemical fertilizers as the sole source of nitrogen (Fig. 6). Similar to our findings, other studies have shown that the use of BRs as the sole source of nitrogen or the partial substitution of chemical fertilizers by a variety of organic fertilizers can maintain nutrient supply and crop yield at similar levels to mineral fertilizers (Sigurnjak et al., 2017; Sapp et al., 2015; Andruschkewitsch et al., 2013; Alburquerque et al., 2012; Walsh et al., 2012; Zhang et al., 2009). Furthermore, with respect to the rate of nitrogen applied ( 230 and $350 \mathrm{~kg} \mathrm{ha}^{-1}$ ), for both raw digestate and ammonium nitrate, our results support the findings of other studies indicating that higher fertilizer rates do not guarantee higher yields (Sestak et al., 2014), but may also have an adverse effect on nitrogen use efficiency (Yang et al., 2017).

The nitrogen content of the aboveground dry biomass was significantly affected by the fertilization scheme, mainly in the first year of the trial, with grass $\mathrm{N}$ content being the highest under the application of chemical fertilizers, indicating their higher plant availability (Fig. 7). 
This could be partly explained by the fact that nitrogen contained in BRs is mainly in the form of organic nitrogen and $\mathrm{NH}_{4}^{+}-\mathrm{N}$ ( 50 to $80 \%$ of the total $\mathrm{N}$ ). Therefore, the slow release of organically bound $\mathrm{N}$ in the first year of application may result in lower utilization by plants (Gutser et al., 2005) while $\mathrm{NH}_{4}^{+}-\mathrm{N}$ adsorption on the soil matrix may reduce its availability and entail plant root growth towards this nitrogen source. However, the composition of biogas residues may depend on factors such as the type of feedstock and degradability, retention time and conditions within the digester, as well as on further postdigestion treatments. Finally, under warm and aerated soil conditions, $\mathrm{NH}_{4}^{+}-\mathrm{N}$ is susceptible to rapid transformation and assimilation by the soil microbial biomass, and therefore is available to plants only for a short time. The latter can be supported if we take into account the low nitrogen uptake observed under the application of the BR fractions and their lower contribution to nitrate accumulation in the soil profile compared to the unfertilized control in the first year of the experiment (Fig. 5). Hence, we posit that BRs, in contrast to chemical fertilizers, act mainly via the soil N pool (Gutser et al., 2005) by enhancing the activity and biomass of soil microorganisms (Nkoa, 2014), leading to the increased immobilization (Larsen et al., 2007) of available N. In line, Abubaker et al. (2015) concluded that application of BRs on soil could limit nitrogen availability to plants in the short-term. Over the following two years, the biogas residue fractions tested had no statistical differences with the chemical and combinatorial treatments, something that could be ascribed to the residual $\mathrm{N}$ effect, observed also in other studies evaluating the nitrogen fertilizer replacement value of biogas residues (Cavalli et al., 2016) and manure (Schröder, 2005). This outcome suggests that the low degradation rate of organic $\mathrm{N}$ contained in BRs has the potential to gradually supply the soil with nutrients required for plant growth, particularly plants with a constant nitrogen demand, such as perennial forage grasses (De Boer, 2017). It should be noted that in our experiment, fertilization was done by hand and the fertilizers were applied to the soil surface rather than incorporated into the soil to reduce nitrogen losses through ammonia volatilization. Gericke (2009) estimated that emissions following BR application were between 7 and $24 \%$ of the applied $\mathrm{NH}_{4}^{+}-\mathrm{N}$. We believe that the employment of more suitable application methods of BRs (injection, trailing-shoe), that minimize their exposure to air and maximise their contact with the topsoil, could possibly lead to higher nitrogen uptake by the plants. Finally, we should keep in mind that the belowground biomass of grasslands encompasses the main pool of organic matter, with root turnover playing a critical role in nutrient cycling (Fiala, 2010). Therefore, to obtain a comprehensive view of the utilization and physical allocation of the plant available nitrogen, experiments that consider the form of $\mathrm{N}$ provided and simultaneously examine the aboveground and belowground biomass content would be illuminating.

Nitrogen use efficiency indicators, such as the agronomic efficiency and apparent recovery efficiency, revealed a plateau effect under higher fertilization rates, while less than half of the nitrogen applied was retained in the biomass. Particularly for BR fractions, nitrogen use efficiency may be underestimated in short-term trials as plant nutrient requirements may not be met shortly after their application due to residual effects. These observations suggest that local farmers could increase their economic benefits by reducing the fertilization rate both for BRs and chemical fertilizers without having a negative impact on the agronomic performance. In many farming systems, the increase of chemical fertilizers has failed to increase nitrogen use efficiency proportionally, instead leading to environmental problems (Shen et al., 2013). Beside the fertilization rates, another factor that can affect the nutrient use efficiency of fertilizers and consequently the yield production is the deficiency or imbalance of essential plant nutrients, as well as their synergistic and antagonistic interactions (Rietra et al., 2017). Knowledge of these interactions would be of particular interest for biogas residues since they are rich in plant macro- and micronutrients. Therefore, experiments that consider application time, nitrogen amount, nutrient composition of BRs and the nature of nutrient interactions could help to optimize BR use and fine-tune their application according to different conditions and plant requirements.

At last, the results of this study indicated a relationship between the annual precipitation and yield performance, with all the fertilization schemes tested demonstrating a uniform response. The aboveground biomass yield was significantly higher and treatment-independent when the annual rainfall was high, while it was reduced up to $40 \%$ in some cases when the precipitation was low (Fig. 8). According to this field experiment, plant biomass nitrogen was also affected by the annual rainfall. More specifically, plots treated with BRs revealed a positive response to elevating annual precipitation, while plots treated with chemical and combinatorial treatments indicated a dilution effect when annual rainfall exceeded $707 \mathrm{~mm}$ (Fig. 8). It is well known that alterations in the rainfall patterns and the annual mean directly affect the crop yields (Jabloun et al., 2015), the utilization of nutrients and thus, the productivity of agricultural ecosystems (Han et al., 2015). Taking into account our findings, along with the broader nutrient base of BRs, their utilization could be of particular interest in tropical soils with low organic matter content and other deficiencies. Also, in countries where agriculture is limited by inadequate and erratic rainfall, such as in sub-Saharan countries, the use of BRs could possibly unburden soils from nitrate accumulation due to the use of chemical fertilizers, enhance the water holding capacity and increase carbon sequestration (Smith et al., 2014). Although our observations help in better understanding the behaviour of BRs and compare it to that one of chemical fertilizers, these results should not be extrapolated to all soil types, climatic conditions and management systems without local investigation.

\subsection{Health and safety risks associated with biogas residue application}

Beside the environmental and agronomic benefits that may result from the application of biogas residues on agricultural lands, the adverse effects of their use - such as chemical and biological contamination potential - are of paramount importance for the farmers and end users. The effective recycling of organic wastes back into the soil presupposes BRs not only rich in nutrients but also safe for living organisms. BR quality with respect to health and safety depends mainly on the organic wastes used as feedstock and the conditions within the reactor. In biogas plants such as this one, where animal manure is one of the main input materials, the monitoring of BR quality is important. Discussions around the benefits and risks of BRs are very controversial with the main concerns being the spread of pathogens, the accumulation of heavy metals and the presence of organic pollutants and antibiotics. To control the quality of biogas residues intended for land application, in Europe, regulations set up limit values for these contaminants, and provide lists with materials that are suitable as feedstock for the anaerobic digestion process (EU, 2002).

This study was focused on the short-term environmental and agronomic impact of biogas residues when applied on a permanent grassland. As this has been an ongoing field experiment since 2013, we are currently investigating the impact of the various biogas residue fractions, produced at the biogas plant on site (Ferme du Faascht, Attert, Belgium), on the diversity and abundance of autochthonous soil bacteria implicated in nitrogen cycling processes, as well as the potential of soil contamination by pathogens, by exploiting 'omic' approaches. From the existing literature, it is well known that the process of anaerobic digestion, even under the mesophilic temperature of $39^{\circ} \mathrm{C}$, can eliminate or reduce pathogens such as Escherichia coli, Salmonella and Listeria contained in animal effluents (Goberna et al., 2011). Recent studies have reported plant disease suppression (Fuchs et al., 2008), as well as pesticidal (Jothi et al., 2003; Kupper et al., 2006) and insecticidal activity (German National Academy of Sciences Leopoldina, 2012) of biogas residues. However, more resistant microorganisms such as spore-forming Clostridium perfringens and prions, may survive even after thermophilic digestion (Elmerdahl Olsen and Errebo Larsen, 1987; Franke-Whittle and Insam, 2013). Despite the potential risk, 
under no circumstances does anaerobic digestion increase the spreading risk of bacterial pathogens, especially when compared to undigested manures (Insam et al., 2015). With a retention time of 40 days and a mesophilic operational temperature of $38{ }^{\circ} \mathrm{C}$ for the manure based biomethanation process established in our biogas plant, we hypothesize an adequate sanitation of the produced digestate - particularly for the dried biogas residue fraction produced after post-treatment on a belt dryer. Phytotoxicity due to the heavy metals, organic pollutants and antibiotics contained in BRs is another major concern. Their concentration is also believed to decrease after anaerobic digestion (Möller and Müller, 2012; Varel et al., 2012), although not all of the contaminants can be sufficiently controlled. Maunuksela et al. (2012), with the use of plant bioassays, tested the phytotoxicity of various biogas products in concentrations used in the field conditions, proving their suitability as fertilizers. Various treatment processes of biogas residues are available to ensure that the end products meet the requirements of environmental regulations (Adam et al., 2018). However, there is a need for long-term field experiments regarding heavy metal and organic pollutant build-up in soil and plant tissues. Overall, the composition and quality of BRs intended for fertilization should be closely monitored. Confidence in the safety of biogas residues is expected to promote their use as biofertilizers.

\section{Conclusions}

During this three-year study, biogas residue fractions did not demonstrate any nitrate leaching risk and remained nitrogen rate- and precipitation-independent as opposed to chemical fertilizers. The partial substitution of chemical fertilizers by raw digestate at the level of $65 \%$ was proven to reduce the accumulation of residual nitrate in the soil. The application of BRs as the sole nitrogen source, as well as in combination with chemical fertilizers, demonstrated their potential to maintain yields and nitrogen uptake and concurrently mitigate nitrate leaching risk in this grassland system.

However, more comprehensive studies are required to understand the long-term consequences of repeated biogas residue application on environmental pollution and agronomic performance, and to implement their use in a wider context. Field trials that will shed a light on the destiny of the organic nitrogen accumulated in the soil under fertilization with BRs and the processes that determine its availability in the long-term are in need. Together with quality and safety assessment, different fertilization rates tested in various soils and climatic conditions could help to optimize the use of BRs in agriculture. Finally, global modelling studies regarding climate change - such as the elevation of atmospheric $\mathrm{CO}_{2}$ and unpredictable weather - should be put in perspective to better predict the repercussions of different fertilization practices on the $\mathrm{N}$ cycle and plant production in the future.

Keeping in mind the advantages and disadvantages of the biogas residues and chemical fertilizers evaluated in this field experiment, we can state with optimism that substitution of chemical fertilizers by biogas residues could be an effective approach to an eco-friendly nutrient management in similar agricultural systems.

\section{Acknowledgments}

The authors acknowledge the contribution of the partners of the ECOBIOGAZ (INTERREG-IV-a) and PERSEPHONE (INTERREG V-a) projects: Au pays de l'Attert a.s.b.l., Agria Grand Est, Ama Mundu Technologies, Sustain Water, Biogas Vereenenegung a.s.b.l., Biogas Beckerich, Ecole Nationale Supérieure d'Agronomie et des Industries Alimentaires, Université de Liège, Agra-Ost, IZES gGmbH, Naturgas Kielen, La Ferme du Faascht, Biogas Rohlingerhof, Bio Recycle sarl, Lycée technique Agricole and Université Libre de Bruxelles. Finally, the authors wish to thank the Luxembourgish Administration de la gestion de l'eau du Ministère du Développement Durable et des Infrastructures and the Administration des services techniques de l'agriculture du Ministère de l'Agriculture for providing weather data, Ghislaine Fuchs for the graphical representation, Martin B. Bagaram for the fruitful discussions and his contribution to the data treatment and analysis, and Camille Gira, Luxembourg Secretary of State, for his never ending support to the environmental cause.

\section{Funding}

This work is part of the PERSEPHONE Project, which is a Transfrontier Program for European Territorial Cooperation and is cofinanced by the European Union - European Regional Development Fund 2014-2020 INTERREG VA “Greater Region" and the Ministère du Développement Durable et des Infrastructures (MDDI) of Luxembourg.

\section{References}

Abubaker, J., 2012. Effects of Fertilisation with Biogas Residues on Crop/rYield, Soil Microbiology and Greenhouse Gas|rEmissions - Recycling of Plant Nutrients from Bioenergy Production (Dr. Thesis ISSN 1652-).

Abubaker, J., Risberg, K., Jönsson, E., Dahlin, A.S., Cederlund, H., Pell, M., 2015. Short-term effects of biogas digestates and pig slurry application on soil microbial activity. Appl. Environ. Soil Sci. 2015. https://doi.org/10.1155/2015/658542.

Adam, G., Mottet, A., Lemaigre, S., Tsachidou, B., Trouvé, E., Delfosse, P., 2018. Journal of Environmental Chemical Engineering Fractionation of anaerobic digestates by dynamic nanofiltration and reverse osmosis: an industrial pilot case evaluation for nutrient recovery. J. Environ. Chem. Eng. 6, 6723-6732. https://doi.org/10.1016/j. jece.2018.10.033.

Alburquerque, J.A., de la Fuente, C., Bernal, M.P., 2012. Chemical properties of anaerobic digestates affecting $\mathrm{C}$ and $\mathrm{N}$ dynamics in amended soils. Agric. Ecosyst. Environ. 160, 15-22. https://doi.org/10.1016/j.agee.2011.03.007.

Andruschkewitsch, M., Wachendorf, C., Wachendorf, M., 2013. Effects of digestates from different biogas production systems on above and belowground grass growth and the nitrogen status of the plant-soil-system. Grassl. Sci. 59, 183-195. https://doi. org/10.1111/grs.12028.

Angelidaki, I., Ellegaard, L., Ahring, B.K., 2003. Applications of the anaerobic digestion process. Biomethanation II, pp. 1-35.

Anton, C., Steinicke, H., 2012._Bioenergy - Chances and Limits.

Beaudoin, N., Saad, J.K., Van Laethem, C., Machet, J.M., Maucorps, J., Mary, B., 2005. Nitrate leaching in intensive agriculture in Northern France: effect of farming practices, soils and crop rotations. Agric. Ecosyst. Environ. 111, 292-310. https://doi.org/10.1016/j. agee.2005.06.006.

Bloom, A.J., 2010. Energetics of nitrogen acquisition. Nitrogen Metabolism in Plants in the Post-genomic Era, pp. 63-81 https://doi.org/10.1002/9781444328608.ch3.

Bloom, a J., Caldwell, R.M., Finazzo, J., Warner, R.L., Weissbart, J., 1989. Oxygen and carbon dioxide fluxes from barley shoots depend on nitrate assimilation. Plant Physiol. 91, 352-356. https://doi.org/10.1104/pp.91.1.352.

Bloom, A.J., Sukrapanna, S.S., Warner, R.L., 1992. Root respiration associated with ammonium and nitrate absorption and assimilation by Barley. Plant Physiol. 99, 1294-1301. https://doi.org/10.1104/pp.99.4.1294.

Bloom, A.J., Jackson, L.E., Smart, D.R., 1993. Root growth as a function of ammonium and nitrate in the root zone. Plant Cell Environ. 16, 199-206. https://doi.org/10.1111/ j.1365-3040.1993.tb00861.x

Cameron, K.C., Di, H.J., Moir, J.L., 2013. Nitrogen losses from the soil/plant system: a review. Ann. Appl. Biol. 162, 145-173. https://doi.org/10.1111/aab.12014.

Cavalli, D., Cabassi, G., Borrelli, L., Geromel, G., Bechini, L., Degano, L., Marino Gallina, P., 2016. Nitrogen fertilizer replacement value of undigested liquid cattle manure and digestates. Eur. J. Agron. 73, 34-41. https://doi.org/10.1016/j. eja.2015.10.007.

Chiew, Y.L., Spångberg, J., Baky, A., Hansson, Anders, Jönsson, H., 2015. nvironmental impact of recycling digested food waste as a fertilizer in agriculture-A case study. Resources, Conserv. Recycl. 95, 1-14. https://doi.org/10.1016/j. resconrec.2014.11.015.

Colmer, T.D., Bloom, A.J., 1998. A comparison of NH4+ and NO3- net fluxes along roots of rice and maize. Plant Cell Environ. 21, 240-246. https://doi.org/10.1046/j.13653040.1998.00261.x.

Corré, W.J., Conijn, J.G., 2016. Biogas Production and Digestate Utilisation from Agricultural Residues.

Cuttle, S.P., Scholefield, D., 1995. Management options to limit nitrate leaching from grassland. J. Contam. Hydrol. https://doi.org/10.1007/s10147-016-1036-3.

De Boer, H.C., 2017. Nitrate Leaching From Liquid Cattle Manure Compared to Synthetic Fertilizer Applied to Grassland or Silage Maize in the Netherlands. pp. 1-32.

Delin, S., Stenberg, M., 2014. Effect of nitrogen fertilization on nitrate leaching in relation to grain yield response on loamy sand in Sweden. Eur. J. Agron. 52, 291-296. https:// doi.org/10.1016/j.eja.2013.08.007.

Dobermann, A., 2007. Nutrient use efficiency-measurement and management. IFA International Workshop on Fertilizer Best Management Practices, Brussels, Belgium, 7-9 March 2007, p. 28.

EBA, 2017. Statistical report 2017. Annu. Rep. 68. https://doi.org/10.1139/e11-014

EEC, 1991. Council Directive 91/676/EEC of 12 December 1991 concerning the protection of waters against pollution caused by nitrates from agricultural sources. Off. J. Eur. Communities 31 (12), 1.

Elmerdahl Olsen, J., Errebo Larsen, H., 1987. Bacterial decimation times in anaerobic digestions of animal slurries. Biol. Wastes https://doi.org/10.1016/0269-7483(87)90121-2. 
EU, 2002. European Regulation (EC) No 1774/2002. Laying Down Health Rules Concerning Animal By-products Not Intended for Human Consumption. European Parliament and Council, Brussels, Belgium.

Fdz-Polanco, F., Fdz-Polanco, M., Fernández, N., Urueña, M.A., García, P.A., Villaverde, S., 2001. Combining the biological nitrogen and sulfur cycles in anaerobic conditions. Water Sci. Technol. 44, 77-84. https://doi.org/10.1016/j.biortech.2008.01.054.

Fiala, K., 2010. Belowground plant biomass of grassland ecosystems and its variation according to ecological factors. Ekol. Bratislava 29, 182-206. https://doi.org/10.4149/ ekol_2010_02_182.

Fixen, P., Brenturp, F., Bruulsema, T.W., Garcia, F., Norton, R., Zingore, S., 2015. Nutrient/ fertilizer use efficiency: measurement, current situation and trends. Manag. Water Fertil. Sustain. Agric. Intensif., 8-38 https://doi.org/10.1016/j.ijantimicag.2012.09.018.

Fowler, D., Steadman, C.E., Stevenson, D., Coyle, M., Rees, R.M., Skiba, U.M., Sutton, M.A., Cape, J.N., Dore, A.J., Vieno, M., Simpson, D., Zaehle, S., Stocker, B.D., Rinaldi, M., Facchini, M.C., Flechard, C.R., Nemitz, E., Twigg, M., Erisman, J.W., Butterbach-Bahl, K., Galloway, J.N., 2015. Effects of global change during the 21st century on the nitrogen cycle citation for published version: effects of global change during the 21st century on the nitrogen cycle. Atmos. Chem. Phys. 15, 13849-13893. https://doi.org/ 10.5194/acp-15-13849-2015.

Franke-Whittle, I.H., Insam, H., 2013. Treatment alternatives of slaughterhouse wastes, and their effect on the inactivation of different pathogens: a review. Crit. Rev. Microbiol. https://doi.org/10.3109/1040841X.2012.694410.

Fuchs, J.G., Berner, A., Mayer, J., Smidt, E., Schleiss, K., 2008. Influence of compost and digestates on plant growth and health: potentials and limits. Codis 2008.

Galloway, J.N., Aber, J.D., Erisman, J.W., Seitzinger, S.P., Howarth, R.W., Cowling, E.B., Cosby, B.J., 2003. The nitrogen Cascade. Bioscience 53, 341. https://doi.org/10.1641/ 0006-3568(2003)053[0341:TNC]2.0.CO;2.

Gericke, D., 2009. Measuring and Modeling of Ammonia Emissions after Field Application of Biogas Slurries. (Doctoral thesis). Kiel University, Germany.

German National Academy of Sciences Leopoldina, 2012. Bioenergy e Chances and Limits. Halle (Saale).

Goberna, M., Podmirseg, S.M., Waldhuber, S., Knapp, B.A., García, C., Insam, H., 2011. Pathogenic bacteria and mineral $\mathrm{N}$ in soils following the land spreading of biogas digestates and fresh manure. Appl. Soil Ecol. 49, 18-25. https://doi.org/10.1016/j. apsoil.2011.07.007.

Grant, R., Thorling, L., Hossy, H., 2011. Developments in monitoring the effectiveness of the EU nitrates directive action programmes: approach by Denmark. Dev. Monit. Eff. EU Nitrates Dir. Action Program. 389

Guillard, K., Griffin, G.F., Allinson, D.W., Yamartino, W.R., Rafey, M.M., Pietrzyk, S.W., 1995. Nitrogen utilization of selected cropping systems in the U.S. northeast: II. Soil profile nitrate distribution and accumulation. Agron. J. 87, 199-207. https://doi.org/10.2134/ agronj1995.00021962008700020011x.

Gutser, R., Ebertseder, T., Weber, A., Schraml, M., Schmidhalter, U., 2005. Short-term and residual availability of nitrogen after long-term application of organic fertilizers on arable land. J. Plant Nutr. Soil Sci. 168, 439-446. https://doi.org/10.1002/ jpln.200520510.

Han, M., Okamoto, M., Beatty, P.H., Rothstein, S.J., Good, A.G., 2015. The genetics of nitrogen use efficiency in crop plants. Annu. Rev. Genet. 49, 269-289. https://doi.org/ 10.1146/annurev-genet-112414-055037.

Hawkesford, M.J., Howarth, J.R., 2011. Transcriptional Profiling Approaches for Studying Nitrogen Use Efficiency. 42, pp. 41-62. https://doi.org/10.1002/9781444328608.ch2.

Haynes, R.J., 1986. Uptake and assimilation of mineral nitrogen by plants. Miner. Nitrogen Plant-Soil Syst., 303-378 https://doi.org/10.1016/B978-0-12-334910-1.50010-8.

Huang, P., Zhang, J., Zhu, A., Li, X., Ma, D., Xin, X., Zhang, C., Wu, S., Garland, G., Isadora, E., Pereira, P., 2018. Science of the total environment nitrate accumulation and leaching potential reduced by coupled water and nitrogen management in the Huang-HuaiHai Plain. Sci. Total Environ. 610-611, 1020-1028. https://doi.org/10.1016/j. scitotenv.2017.08.127.

Insam, H., Gómez-Brandón, M., Ascher, J., 2015. Manure-based biogas fermentation residues - friend or foe of soil fertility? Soil Biol. Biochem. https://doi.org/10.1016/j. soilbio.2015.02.006.

Jabloun, M., Schelde, K., Tao, F., Olesen, J.E., 2015. Effect of temperature and precipitation on nitrate leaching from organic cereal cropping systems in Denmark. Eur. J. Agron. 62, 55-64. https://doi.org/10.1016/j.eja.2014.09.007.

Jackson, L.E., Burger, M., Cavagnaro, T.R., 2008. Roots, nitrogen transformations, and ecosystem services. Annu. Rev. Plant Biol. 59, 341-363. https://doi.org/10.1146/annurev. arplant.59.032607.092932.

Jensen, L.S., Schjoerring, J.K., Van Der Hoek, K.W., Poulsen, H.D., Zevenbergen, J.F., Pallière, C., Lammel, J., Brentrup, F., Jongbloed, A.W., Willems, J., Van Grinsven, H., Jensen, L.S., 2011. Benefits of nitrogen for food, fibre and industrial production. The European Nitrogen Assessment https://doi.org/10.1017/CBO9780511976988.006.

Jothi, G., Pugalendhi, S., Poornima, K., Rajendran, G., 2003. Management of root-knot nematode in tomato Lycopersicon esculentum, Mill., with biogas slurry. Bioresour. Technol. https://doi.org/10.1016/S0960-8524(03)00047-6.

Kirchmann, H., Ryan, M.H., Bergström, L., 2007. Plant nutrient use efficiency in organic farming - consequences of exclusive use of organic manures and untreated minerals. CAB Rev. Perspect. Agric. Vet. Sci. Nutr. Nat. Resour. 2. https://doi.org/10.1079/ PAVSNNR20072076 (12 pp.-12 pp.).

Koszel, M., Lorencowicz, E., 2015. Agricultural use of biogas digestate as a replacement fertilizers. Agric. Agric. Sci. Procedia 7, 119-124. https://doi.org/10.1016/j. aaspro.2015.12.004.

Kupper, K.C., Bettiol, W., de Goes, A., de Souza, P.S., Bellotte, J.A.M., 2006. Biofertilizer for control of Guignardia citricarpa, the causal agent of citrus black spot. Crop Prot. https://doi.org/10.1016/j.cropro.2005.09.002.

Larsen, T., Luxhøi, J., Magid, J., Jensen, L.S., Krogh, P.H., 2007. Properties of anaerobically digested and composted municipal solid waste assessed by linking soil mesofauna dynamics and nitrogen modelling. Biol. Fertil. Soils https://doi.org/10.1007/s00374007-0178-X.

Lenka, S., Singh, A.K., Lenka, N.K., 2013. Soil water and nitrogen interaction effect on residual soil nitrate and crop nitrogen recovery under maize-wheat cropping system in the semi-arid region of northern India. Agric. Ecosyst. Environ. 179, 108-115. https://doi.org/10.1016/j.agee.2013.08.001.

Lenth, R.V., 2016. Least-squares means: the R package lsmeans. J. Stat. Softw. 69. https:// doi.org/10.18637/jss.v069.i01.

Liu, W.K., Yang, Q.C., Du, L., 2009. Soilless cultivation for high-quality vegetables with biogas manure in China: feasibility and benefit analysis. Renewable Agric. Food Syst https://doi.org/10.1017/S1742170509990081.

Losak, T., Hlusek, J., Zatloukalova, A., Musilova, L., Vitezova, M., Skarpa, P., Zlamalova, T., Fryc, J., Vitez, T., Marecek, J., Martensson, A., 2014. Digestate from biogas plants is an attractive alternative to mineral fertilisation of kohlrabi. J. Sustain. Dev. Energy, Water Environ. Syst. 2, 309-318. https://doi.org/10.13044/j.sdewes.2014.02.0025.

Lukehurst, C., Frost, P., Seadi, T. Al, 2010. Utilisation of digestate from biogas plants as biofertiliser. IEA Bioenergy 1-36.

Makowski, D., 2018. The psycho package: an efficient and publishing-oriented workflow for psychological science. J. Open Source Softw. 3, 470. https://doi.org/10.21105/ joss.00470.

Marchi, E.C.S., Zotarelli, L., Delgado, J.A., Rowland, D.L., Marchi, G., 2016. Use of the Nitrogen Index to assess nitrate leaching and water drainage from plastic-mulched horticultural cropping systems of Florida. Int. Soil Water Conserv. Res. 4, 237-244. https:// doi.org/10.1016/j.iswcr.2016.12.001

Marschner, M., 2012. Mineral Nutrition of Higher Plants, Marschner's Mineral Nutrition of Higher Plants. Third edition. https://doi.org/10.1016/B978-0-12-384905-2.00017-0.

Maunuksela, L., Herranen, M., Torniainen, M., 2012. Quality assessment of biogas plant end products by plant bioassays. Int. J. Environ. Sci. Dev. 3, 305-310.

Möller, K., 2015. Effects of Anaerobic Digestion on Soil Carbon and Nitrogen Turnover, N Emissions, and Soil Biological Activity. A Review. , pp. 1021-1041 https://doi.org/ 10.1007/s13593-015-0284-3.

Möller, K., Müller, T., 2012. Effects of anaerobic digestion on digestate nutrient availability and crop growth: a review. Eng. Life Sci. https://doi.org/10.1002/elsc.201100085.

Monaghan, R.M., Barraclough, D., 1992. Some chemical and physical factors affecting the rate and dynamics of nitrification in urine-affected soil. Plant Soil 143, 11-18. https:// doi.org/10.1007/BF00009124.

Moniteur Belge, 2013. Arrêté ministériel portant certaines dispositions d'exécution relatives aux techniques de mesure de l'azote potentiellement lessivable et au(survey surfaces agricoles) en application du chapitre IV de la partie réglementaire du Code de l'Environnement constituant le Code de l'Eau, Deuxieme Edition.

Nkoa, R., 2014. Agricultural benefits and environmental risks of soil fertilization with anaerobic digestates: a review. Agron. Sustain. Dev. https://doi.org/10.1007/s13593013-0196-z.

Odlare, M., Pell, M., Svensson, K., 2008. Changes in soil chemical and microbiological properties during 4 years of application of various organic residues. Waste Manag. 28 , 1246-1253. https://doi.org/10.1016/j.wasman.2007.06.005.

Philippot, L., Hallin, S., Schloter, M., 2007. Ecology of denitrifying prokaryotes in agricultural soil. Adv. Agron. https://doi.org/10.1016/S0065-2113(07)96003-4.

Rietra, R.P.J.J., Heinen, M., Dimkpa, C.O., Bindraban, P.S., 2017. Effects of nutrient antagonism and synergism on yield and fertilizer use effects of nutrient antagonism and synergism on yield and fertilizer use efficiency. Commun. Soil Sci. Plant Anal. 48, 1895-1920. https://doi.org/10.1080/00103624.2017.1407429.

Sapp, M., Harrison, M., Hany, U., Charlton, A., Thwaites, R., 2015. Comparing the effect of digestate and chemical fertiliser on soil bacteria. Appl. Soil Ecol. 86, 1-9. https://doi. org/10.1016/j.apsoil.2014.10.004.

Scherer, H.W., Feils, E., Beuters, P., 2014. Ammonium fixation and release by clay minerals as influenced by potassium. Plant Soil Environ. 60 (7), 325-331.

Schröder, J., 2005. Revisiting the agronomic benefits of manure: a correct assessment and exploitation of its fertilizer value spares the environment. Bioresource Technology https://doi.org/10.1016/j.biortech.2004.05.015.

Seadi, T. Al, Lukehurst, C., Saedi, T. Al, Lukehurst, C., Seadi, T. Al, Lukehurst, C., 2012. Quality management of digestate from biogas plants used as fertiliser. IEA Bioenergy, Task 40.

Sestak, I., Mesic, M., Zgorelec, Z., Kisic, I., Basic, F., 2014. Winter wheat agronomic traits and nitrate leaching under variable nitrogen fertilization. Plant Soil Environ. 60, 394-400.

Shen, J., Li, Y., Liu, X., Luo, X., Tang, H., Zhang, Y., Wu, J., 2013. Atmospheric dry and wet nitrogen deposition on three contrasting land use types of an agricultural catchment in subtropical central China. Atmos. Environ. 67, 415-424. https://doi.org/10.1016/j. atmosenv.2012.10.068.

Sigurnjak, I., Vaneeckhaute, C., Michels, E., Ryckaert, B., Ghekiere, G., Tack, F.M.G., Meers, E., 2017. Fertilizer performance of liquid fraction of digestate as synthetic nitrogen substitute in silage maize cultivation for three consecutive years. Sci. Total Environ. 599-600, 1885-1894. https://doi.org/10.1016/j.scitotenv.2017.05.120.

Smith, J., Abegaz, A., Matthews, R.B., Subedi, M., Orskov, E.R., Tumwesige, V., Smith, P. 2014. What is the potential for biogas digesters to improve soil carbon sequestration in Sub-Saharan Africa? Comparison with other uses of organic residues. Biomass and Bioenergy https://doi.org/10.1016/j.biombioe.2014.01.056.

Sutton, M.A., Howard, C.M., Erisman, J.W., Bealey William, J., Billen, G., Bleeker, A. Bouwman, A.F., Grennfelt, P., Van Grinsven, H., Grizzetti, B., 2011. The challenge to integrate nitrogen science and policies: the European Nitrogen Assessment approach. The European Nitrogen Assessment, pp. 82-96 https://doi.org/10.1017/ CBO9780511976988.008.

Svoboda, N., Taube, F., Wienforth, B., Kluß, C., Kage, H., Herrmann, A., 2013. Nitrogen leaching losses after biogas residue application to maize. Soil Tillage Res. 130 69-80. https://doi.org/10.1016/j.still.2013.02.006. 
Taylor, A.R., Bloom, A.J., 1998. Ammonium, nitrate, and proton fluxes along the maize root. Plant Cell Environ. 21, 1255-1263. https://doi.org/10.1046/j.13653040.1998.00357.x.

Tinker, P.B., Nye, P.H., 2000. Book Review Solute Movement in the Rhizosphere. 464. Oxford Univ. Press. https://doi.org/10.1046/j.1365-2389.2001.00418-2.x.

Tsachidou, B., Delfosse, P., Hissler, C., 2018. PERSEPHONE: Using Biogas Residues to Mitigate Agricultural Nitrogen Pollution. Smart Farming - Introd. to Spec. Theme ERCIM News. 113 p. 39

Varel, V.H., Wells, J.E., Shelver, W.L., Rice, C.P., Armstrong, D.L., Parker, D.B., 2012. Effect of Anaerobic Digestion Temperature on Odour, Coliforms and Chlortetracycline in Swine Manure or Monensin in Cattle Manure * 2004. , pp. 705-715 https://doi.org/ 10.1111/j.1365-2672.2012.05250.x

Velthof, G.L., Lesschen, J.P., Webb, J., Pietrzak, S., Miatkowski, Z., Pinto, M., Kros, J., Oenema O., 2014. The impact of the Nitrates Directive on nitrogen emissions from agriculture in the EU-27 during 2000-2008. Sci. Total Environ. 468-469, 1225-1233. https://doi. org/10.1016/j.scitotenv.2013.04.058.

Walsh, J.J., Jones, D.L., Edwards-Jones, G., Williams, A.P., 2012. Replacing inorganic fertilizer with anaerobic digestate may maintain agricultural productivity at less environmental cost. J. Plant Nutr. Soil Sci. 175, 840-845. https://doi.org/10.1002/ jpln.201200214.
Wang, C., Wan, S., Xing, X., Zhang, L., Han, X., 2006. Temperature and soil moisture interactively affected soil net $\mathrm{N}$ mineralization in temperate grassland in Northern China. Soil Biol. Biochem. 38, 1101-1110. https://doi.org/10.1016/j.soilbio.2005.09.009.

Wienhold, B.J., Trooien, T.P., Reichman, G.A., 1995. Yield and Nitrogen Use Efficiency of Irrigated Corn in the Northern Great Plains.

Yang, X., Lu, Y., Ding, Y., Yin, X., Raza, S., Tong, Y., 2017. Optimising nitrogen fertilisation: a key to improving nitrogen-use efficiency and minimising nitrate leaching losses in an intensive wheat/maize rotation (2008-2014). F. Crop. Res. 206, 1-10. https://doi.org/ 10.1016/j.fcr.2017.02.016.

Yao, Z., Zhang, D., Yao, P., Zhao, N., Li, Y., Zhang, S., Zhai, B., Huang, D., Ma, A., Zuo, Y., Cao, W., Gao, Y., 2018. Optimizing the synthetic nitrogen rate to balance residual nitrate and crop yield in a leguminous green-manured wheat cropping system. Sci. Total Environ. 631-632, 1234-1242. https://doi.org/10.1016/j.scitotenv.2018.03.115.

Zhang, X., Meng, L., Wang, Q.J., Huang, Q.W., Xu, Y.C., Yang, X.M., Shen, Q.R., 2009. Effects of Organic-inorganic Mixed Fertilizers on Rice Yield and Nitrogen Use Efficiency. NCBI.

http://www.requaconsult.requasud.be/ (Feb. 2019). 